\title{
You Can't Take It With You: Sunset Provisions for Equity Compensation When Managers Retire, Resign, or Die
}

\author{
Sandeep Dahiya ${ }^{\mathrm{a}}$ and David Yermack ${ }^{\mathrm{b}}$
}

September 2006

\begin{abstract}
Company stock option plans have diverse "sunset" policies for modifying terms of options held by managers who exit the firm. In our S\&P 500 sample, these forfeiture, vesting, and expiration provisions are less generous in companies characterized by fast growth, dependence on skilled human capital, and high strategic interaction with competitors. We show that these features of firms' option plans directly impact management turnover, early exercise of stock options, and the availability of data about early exercises. For CEOs over age 60, companies' sunset rules generally imply large discounts to option award values and estimates of total compensation.

The authors appreciate helpful comments from Manuel Ammann, Patrick Bolton, Jennifer Carpenter, Don Chance, Stephen Choi, John Core, Joan Heminway, Tracie Woidtke, and seminar participants at Georgetown University, Mannheim University, University of St. Gallen, University of Tennessee, and the Gerzensee European Summer Symposium in Financial Markets.
\end{abstract}

\footnotetext{
${ }^{\mathrm{a}}$ Department of Finance, McDonough School of Business, Georgetown University, 37th and O Sts., NW, Washington, DC 20057. (202) 687-3808. sd@georgetown.edu.

${ }^{\mathrm{b}}$ Department of Finance, Stern School of Business, New York University, 44 West $4^{\text {th }}$ St., Suite 9-160, New York, NY 10012. (212)998-0357.dyermack@stern.nyu.edu.
} 


\section{You Can't Take It With You: \\ Sunset Provisions for Equity Compensation \\ When Managers Retire, Resign, or Die}

\section{Introduction}

This study investigates how companies treat executive stock options when managers leave their positions due to retirement, resignation, or death. The substantial literature analyzing executive options generally assumes that they terminate immediately or within a short period after managers exit the firm. ${ }^{1}$ In reality, companies have diverse policies, which we call "sunset" regulations, for how to modify the options of managers who leave the firm. These policies can lead to major changes in awards' vesting schedules and expiration dates, in ways that could either increase or reduce the options' value. Higher option value could result from acceleration of vesting schedules when an executive leaves. Decreases in value could result from two distinct factors that we refer to as forfeiture and truncation. Forfeiture occurs when an executive's options are canceled with no possibility of exercise, and truncation occurs when options' time to

\footnotetext{
${ }^{1}$ For example, the stopping state model introduced by Carpenter (1998) requires that when leaving the firm, "the executive exercises the option if it is in the money and vested, or else forfeits the option." A survey of option pricing models by Ammann and Seiz (2004) includes a similar characterization, common to a wide range of models, that "if the employee leaves after the vesting period, the option is forfeited if it is out of the money and exercised (immediately) if it is in the money." A theory paper by Bulow and Shoven (2004) opens with the assertion that "Most employee options must be exercised within 90 days of the termination of employment." The authors give no empirical support for this claim, which they use to motivate a proposal to account for all vested stock options as 90-day options, extended every quarter.
} 
expiration is shortened.

As we show below, sunset rules significantly impact such variables as the frequency of management turnover and the time at which employee stock options are exercised. Early exercises play a critical role in firms' choices about how to value and account for executive stock options, and we believe our findings represent an important contribution to this ongoing area of inquiry. Our results indicate that early exercise patterns are not entirely voluntary and can be partly predicted from observable details of option plans that vary across companies. Moreover, we show that the raw data publicly disclosed about early exercise is biased, with more securities filings made by executives from companies that have stringent sunset rules requiring quick exercise of options when managers leave.

Although precise data do not exist to indicate how frequently sunset rules impact the value of equity compensation, we can infer some basic estimates by studying option holdings and executive turnover in the population of top managers covered by the ExecuComp database for our sample of S\&P 500 companies. Within this group, the annual turnover frequency is approximately 12.8 percent, implying that the half-life of a typical manager's stay with each firm is just over five years and the expected career is about 7.6 years. $^{2}$ At the end of their last years listed on ExecuComp, on average managers hold approximately 5.4 years worth of unexercised option awards. These data imply that a clear majority of option exercises take place after the time that managers leave their companies, and further inspection of the data indicates that

\footnotetext{
2 Turnover rates for lower-level employees are probably much higher than these estimates for top managers, implying even greater importance for firms' sunset rules. Although employee turnover data does not exist for individual companies, we tabulate industry level turnover data compiled by the U.S. Bureau of Labor Statistics between 2001 and 2006 in its monthly Job Openings and Labor Turnover Survey (JOLTS). If firms in our sample conformed to their industry averages, their mean annual turnover rate, both voluntary and involuntary, for all workers would be 34.0 percent.
} 
managers often exercise large numbers of additional options just before leaving. These patterns imply that firms' sunset rules for vesting, forfeiture, and truncation eventually become operative for most option awards.

The effects of sunset rules upon a representative option award are illustrated by Figures Ia and Ib, in which we illustrate how two well-known S\&P 500 companies, Time Warner and Viacom, treat the options of managers who retire according to rules disclosed in shareholderapproved option plans filed by each company with the Securities and Exchange Commission. In Figure Ia, the top illustration shows that Time Warner's option awards consist of four equal tranches, one of which becomes exercisable on each of the first through fourth anniversaries of the award date, and all of which expire after ten years. The lower illustration shows how these tranches are treated if a manager retires from the company one year after receiving an option award. ${ }^{3}$ According to Time Warner's policies, all tranches vest immediately at retirement, but their expiration is shortened to five years from the retirement date, effectively turning ten-year options into six-year options in our example. As shown in Table 1, an executive who expected ex ante to retire from Time Warner one year after his option award date would perceive the Black-Scholes value of these options as being 16 percent lower as a result of the foreseen truncation of their original expiration. ${ }^{4}$

Viacom is a company similar to Time Warner in size and industry, and it also awards ten-

\footnotetext{
${ }^{3}$ A large number of companies require forfeiture of all options if an executive does not stay with the firm for at least one year after the award date. For that reason, in most of our models and calculations we adopt the convention of assuming that managers leave the company, for whatever reason, one year or more after the award date.

${ }^{4}$ We use the Black-Scholes approach for ease of calculation. Many other valuation techniques have been applied to executive options, including binomial, stopping state, lattice, and utility-based models. Most of our analysis focuses upon the relative loss in option value caused by different sunset regulations, and we believe that within reasonable tolerances, these relative differentials should generally be invariant to the choice of valuation model. See Ammann and Seiz (2004).
} 
year options that vest ratably over the first four anniversaries after the award date. However, as shown in Figure Ib, executives who retire from Viacom obtain far less generous treatment of their options than those who retire from Time Warner. If an executive retires one year after receiving a new option award, Viacom's option plan requires forfeiture of the three unvested tranches, representing three-fourths of the entire award, and the remaining tranche has its expiration truncated from the tenth anniversary of the award date to the fourth. Together, these changes, if anticipated ex ante by a manager expecting to retire, would reduce the award date value of the option by about 83 percent, as shown in Table 1 .

We study the cross-sectional determinants of firms' policies for option vesting, truncation and forfeiture when managers leave. Our results are generally consistent with a "golden handcuffs" view under which companies use option terms to protect their stocks of human capital, as value losses to optionees who leave the firm tend to be greatest in firms with the largest needs to attract and retain highly skilled workers. Consistent with this interpretation, regression analysis shows that firms' rules for option truncation significantly affect their frequencies of top executive turnover.

After illustrating a connection between firms' sunset rules and their executive turnover, we study whether this pattern influences the early exercise of options at our sample companies. We find two effects. First, early option exercise as inferred from individual executives' Form 4 SEC filings is affected significantly by company vesting schedules, as those firms with later vesting also experience later exercise, according to the available data. Second, we find that the raw data from Form 4 filings is systematically biased. In particular, companies with lenient option truncation rules have substantially fewer Form 4 filings than other firms, when scaled by 
the total volume of option exercises within each company. It is quite likely that these firms' options are held the longest and exhibit the least amount of early exercise, due to the leniency of their sunset rules. We therefore conclude that studies showing systematic early exercise of executive options (for example, Bettis, Bizjak, and Lemmon (2005)) may include overrepresentation of executives whose company plans require quick exercise of options upon leaving the firm, and under-representation of executives from firms that allow retention of options for long periods. We conjecture that stopping-state models used to value executive options (Carpenter (1998)) may be too conservative, since these models take no account of executives' ability to retain their options for significant periods after leaving their firms.

Finally, we study the impact of firms' sunset rules upon estimates of the value of executive compensation. Especially for executives in their early- to mid-60s near retirement age, sunset policies for options can materially affect options' apparent award date values. Below we use simulations to assess the valuation consequences of these regulations firm by firm, and we conclude that the sample mean value of new option awards should be reduced by more than half, and total CEO compensation should be reduced by as much as 25 percent, for CEOs aged 65 and older, if one assumes that these CEOs expect to retire in one year. We also derive large discounts to estimated means of option compensation and total compensation for CEOs at all ages above 60 , based upon an assumption that these CEOs expect to retire at age 65 . The results suggest that accounting regulations such as FAS 123R should take into account an executive's age and the details of companies' option plan regulations when estimating the cost of executive options to an issuing company.

Our research adds to a relatively thin literature of four papers that have studied aspects of 
inter-firm differences in the design and implementation of executive stock option plans. These studies include Kole (1997), who examines companies' different vesting rules for options; Pasternack and Rosenberg (2003), who study exercise prices and dividend protection as used in the option plans of Finnish firms; Chen (2004), who studies repricing restrictions in U.S. firms' option plans; and Sautner and Weber (2006), who examine a variety of aspects of European companies' option plans. The Sautner and Weber study is the most comprehensive to date, but the variables it examines, including accounting choices, completeness of disclosure, and performance targets for options to become exercisable, have little relevance for U.S. firms. American companies face mandatory regulations in disclosing and accounting for option compensation, and performance targets for options to become exercisable remain relatively rare in the U.S. and almost never appear as mandatory terms in firms' option plans.

The remaining sections of this paper are organized as follows. Section II provides a description of the data and an overview of different option sunset rules. Section III studies cross-sectional differences in sunset rules among companies. Section IV provides analysis indicating that sunset rules have significant associations with rates of executive turnover. Section V studies associations between sunset rules and the early exercise of options. Section VI analyzes the valuation impact of option sunset rules, estimating the apparent reduction in value of new option awards to managers who are near expected dates of retirement. Section VII contains conclusions.

\section{Data description}

\section{A. Data collection}


We obtain copies of the most recent shareholder-approved equity compensation plans in effect for all companies in the Standard \& Poor's 500 index in the Fall of 2005. SEC disclosure rules require the full text of each plan to be filed as an attachment to a Form 10-K, 10-Q, 14-A (proxy statement), or 8-K during the fiscal quarter in which the plan goes into effect. In each subsequent year, a company's 10-K filing includes an Exhibit Index cross-referencing the documents where one can obtain the full text of all compensation plans then in effect. Some compensation plans use vague or general language and leave the specific terms of compensation awards to the discretion of a board of directors subcommittee (usually its compensation or stock option committee). If not present in the compensation plan itself, frequently the key details of option awards, such as vesting periods and forfeiture or truncation upon an employee's departure, can be found in a term sheet that is written by this board subcommittee and also filed with the SEC as an attachment to one of the above forms.

Equity compensation plans in many firms also provide for restricted stock, performance shares, or other derivative forms of equity pay. We limit our analysis to stock options, because their role in executive compensation is far larger than these other instruments. Our reading of many firms' plans indicates that restricted stock, when authorized, very often has sunset rules for vesting and forfeiture exactly matching those for stock options, so we believe our conclusions about option compensation apply in a straightforward way to all types of equity pay.

Table 2 indicates that we locate the option plans and/or term sheets for 389 of the 500 companies in the S\&P 500 index, and these firms comprise the sample for analysis presented below. Of the 111 S\&P 500 companies not in our sample, the large majority lack an SEC filing describing their sunset rules with adequate specificity. A minority of missing firms, 21 
companies, are omitted because they either have no option plan in effect or have recently

announced an intention to stop awarding options as compensation.

Our data collection focuses on two aspects of stock options: whether the expiration date changes when an executive leaves the firm, and whether provisions for vesting or exercisability change.

\section{B. Changes to option life}

Table 3 presents basic summary statistics about option life before and after an employee leaves the firm. In the top half of the table, data indicate that ten-year options are awarded by an overwhelming majority of companies, in line with a longstanding practice that can be traced to personal income tax rules that require options to expire in ten years or less. The lower half of Table 3 shows how much option life is retained by managers who leave their companies, and the full distributions of these data are plotted in Figure II. We report the maximum time permitted for executives to exercise their options; in cases in which the option already had less life remaining than the maximum permitted under the plan, the shorter time will apply. ${ }^{5}$ We tabulate data for three different types of departures: resignations, retirements, and deaths. ${ }^{6}$ Resignations are mid-career departures of executives who presumably will take other jobs, perhaps with competitors of the firm awarding the option. Retirements are distinguished from resignations in

\footnotetext{
${ }^{5}$ A small number of companies permit minor increases in option life under certain conditions; for example, in cases of death some firms leave intact the expiration date of the decedent's options but specify that the estate will have no less than 6 months to exercise should the options' expiration be imminent. Because these adjustments are rare, generally small, and incompatible with most of our data definitions, we do not incorporate them into our analysis.

6 These three types of departures are mentioned in nearly every company's plan. A significant minority of firms have additional rules for departures that occur for such reasons as layoffs (involuntary terminations) or permanent disability. When present, we find that the sunset rules for layoffs are often close to identical to the rules for resignations, and the rules for disability are very similar to those for cases of death.
} 
most firms by a formula tied to age and years of service, though more than half of our sample companies do not make clear disclosures of these guidelines. In a minority of companies, no distinction is drawn between resignation and retirement, and the same sunset provisions for equity pay apply in either case. Deaths in office are analyzed as a benchmark for the other two categories of departure; deaths present a useful baseline because of the complete absence of any moral hazard issue related to the executive's departure from the firm, as well as the lack of concern that the executive may go on to work elsewhere. ${ }^{7}$

Data in Table 3 and Figure II show that mid-career resignations generally lead to elimination of the large majority of option life, as more than 85 percent of companies give managers three months or less to exercise their options after a resignation (just over half of company resignation policies appear to follow the 90-day rule that is the focus of the model in Bulow and Shoven (2004), though the fraction is far less for retirements and deaths). Retirements are treated much differently. The mean and median option life retained when executives retire is 4.4 and 3.0 years, respectively, and a significant fraction of companies permit executives to hold their options for their full term in cases of retirement. For deaths in office, the deceased executive's heirs or estate inherit the right to exercise the option, and the mean and median periods permitted for exercise are 3.2 and 1.0 years, respectively. Figure II shows that, in terms of firms' leniency toward option holders, death represents an intermediate state between resignation, which generally leads to large reductions in option values, and retirement, in which

\footnotetext{
${ }^{7}$ One firm, Synovus Financial, goes to great length to distinguish between suicides and other causes of death in its 2002 Long Term Incentive Plan, which mentions suicide no less than eight times. Similar to other companies, Synovus in cases of death provides for accelerated vesting of equity compensation and a long period for the optionee's estate to exercise, but only if the deceased manager did not take his own life. The company did not respond to our inquiry asking about the reasons for this safeguard against the moral hazard problem of executives killing themselves in order to achieve more rapid vesting of their options.
} 
optionees are often treated generously.

\section{Changes in vesting schedules}

Along with the possible truncation of option maturity, equity compensation plans also include regulations for how to treat options that have not yet vested at the time that an executive leaves his firm. In this case, sunset rules could lead either to a reduction of option value, which would occur if the unvested options are forfeited in whole or in part, or possibly an increase in value, if the executive's departure triggers more rapid vesting of options than would be the case if he stayed employed. ${ }^{8}$ Detail about these regulations appears in Table 4.

The table begins with information about the overall vesting schedules for firms in the sample. Of the 389 firms that we study, we were unable to determine vesting rules for 30 , although we do know their sunset rules for treatment of unvested options (whatever the vesting schedule) when an optionee leaves. The remaining 359 firms for which we have complete information feature 89 distinct vesting schedules; the most popular schedules call for annual vesting of awards in three or four tranches at each anniversary of the award date. ${ }^{9}$ To analyze the wide range of schedules, we summarize vesting information using a handful of statistics, including the weighted average time for a company's entire award to vest, the median time to vest (the time after which half of more of the options are exerciseable), and the time for 100

\footnotetext{
${ }^{8}$ Earlier vesting would increase the options' subjective value to an employee. However, it could also reduce the expected cost to shareholders by triggering value-destroying earlier exercise.

${ }^{9}$ Some firms make option awards with several different vesting schedules, even though the awards might occur in the same year. In such cases we use the most common schedule, which can usually be ascertained easily from information in the annual proxy statement. A small minority of firms attach performance conditions to the vesting of option awards, particularly for managers at the very top of the hierarchy such as the CEO. We ignore these contingent vesting schedules for purposes of this study and focus instead on vesting schedules for generic options.
} 
percent of an award to vest. Panel A at the top of Table 4 presents information about these statistics. The data indicate that the weighted average time for an award to vest is about two and a half years, and the median vesting time is about two years; these statistics imply that many firms have similar or identical vesting schedules as the two illustrated in Figures Ia and Ib.

In the center of Table 4, Panel B shows information about the treatment of unvested options for executive departures in the three categories of resignation, retirement, and death. The treatments range from immediate accelerated vesting, the most favorable case, which is shown in the top row, and forfeiture of all unvested options, the most punitive case, which is shown in the bottom row. Clear disparities exist in the treatment of options across the three states. Nearly all companies - 96 percent of the sample - cancel unvested options in cases of resignation, but these forfeiture frequencies are much smaller -44 percent and 35 percent - in cases of retirement and death, respectively. About 60 percent of firms allow for immediate or continuing vesting of options in cases of death, and about 50 percent of firms do so for retirees. ${ }^{10}$ As shown in the table, a small minority of firms have regulations that call for partial forfeiture of unvested options in any or all of the three types of separations, with the fraction of options forfeited calculated according to a fixed rule or a pro rata schedule with respect to the passage of time since the award date.

D. Relation between changes in option life and changes in vesting schedules

Data from Tables 3 and 4 indicate that optionees can lose substantial value when leaving

\footnotetext{
${ }^{10}$ Options that continue on their original vesting schedules will eventually become exercisable with the passage of time, unless the firm also has truncation rules (see above) that shorten the option life so that the new expiration date falls before the completion of vesting.
} 
their firms either because of the truncation of option life or the forfeiture of unvested options. An obvious question is whether these two types of adjustments operate as substitutes, complements, or orthogonally, and Panel $\mathrm{C}$ presents data showing an umambiguous complementary relationship. For all three types of executive departure, the panel compares the average option life retained by optionees who receive the most lenient treatment of unvested options - immediate, accelerated vesting - to those who receive the harshest treatment complete forfeiture. The average life retained is far higher in firms that provide for accelerated vesting. The data therefore show that when firms wish to recoup option value from executives who leave the company, they tend to do so in two ways at once, both shortening the options' lives and canceling options that have not yet vested.

\section{Cross-sectional determinants of sunset rules}

Having described the distribution of sunset rules across companies, we now analyze how the strength of these rules varies cross-sectionally. We focus on sunset rules that go into effect when employees retire; we study rules for retirements instead of resignations because they exhibit more diversity across firms, as shown earlier in Tables 3 and 4 and Figure II.

Because sunset rules take effect when an executive leaves the company, our basic hypotheses are derived from well-known theories about how equity compensation is used to bind valuable executives to their firms. Many papers, beginning at least with Smith and Watts (1992) and probably earlier, highlight the role of equity pay as a retention device in industries where management skill is required to select and develop investment opportunities. Core and Guay (2001) elaborate on how this theory applies to option programs broadly targeting all of a firm's 
employees. We follow these theories and predict that sunset rules will be stronger, that is, less generous toward employee option holders, when human capital is a valuable input to a firm's production process. In other words, we expect option programs in knowledge-based companies to have strong "golden handcuff" components, including longer vesting periods when optionees are still employed and harsher forfeiture rules and truncations of maturity when optionees leave. $^{11}$

Table 5 presents descriptive statistics about the key variables used in our regression analysis of the strength of sunset rules. The first three lines of the table reproduce data introduced in the previous section to describe options' vesting schedules, the time permitted for retirees to exercise, and forfeiture of unvested options at retirement. The next two lines present two variables that we calculate by transforming our basic data about sunset rules into economic measures of their value consequences.

We construct a measure of the percent of option award value lost when a hypothetical 65year-old employee at each sample firm receives a new option award and then retires one year later. So that our variable will show clearly the effects of forfeiture and truncation rules, we use fixed assumptions for all companies for the exercise price $(\$ 25.00)$, stock price $(\$ 25.00)$, volatility $(0.30)$, dividend rate $(0.015)$, and and risk-free rate $(0.045)$, and we calculate a benchmark Black-Scholes option value for each firm under these assumptions. We then determine how this benchmark value would change if the executive retired one year after the

\footnotetext{
11 An opposite prediction about sunset rules and executive retirements would be implied by the "horizon problem" studied by Dechow and Sloan (1991) and others, who present arguments about why firms should award equity compensation to executives near the end of their careers, especially in companies with valuable investment opportunities. If firms wished to encourage managers of these firms to hold equity during their retirements, one would expect more generous sunset rules in firms with valuable human capital.
} 
award, with the firm's rules about vesting, forfeiture, and maturity truncation becoming operational at that time. Table 5 shows that the median retirement adjustment to options reduces their award value by 65.7 percent, and the inter-quartile range of this variable is quite large, from 22.3 percent at the top of the first quartile to 91.4 percent at the top of the third.

To measure the degree to which a firm's sunset rules discourage employees from working elsewhere after they retire, we compare each firm's treatment of options for executives who retire with options held by those who die. Specifically, we calculate the value lost for an executive who receives a new option award at age 65 and then dies one year later. We then compare the value losses for executives who die and those who retire (using the variable above), and create a binary $(0,1)$ variable that equals one if the retirement value loss is equal to or greater than the death loss. Firms for which the value equals one would appear to be those most concerned about the possibility of a retired executive working elsewhere, since this cannot happen when executives die. Table 5 shows that 36 percent of companies have sunset rules that take greater option value away from retirees compared to decedents.

These five variables, listed in the top rows of Table 5, serve as our dependent variables in cross-sectional regressions measuring the strength of firms' sunset rules. Our regressions, reported in Tables 6 and 7 below, are estimated for option plans in effect in late 2005, so all financial data is generally measured or calculated with respect to the year 2004.

We use a number of explanatory variables to proxy for the degree to which firms' place a high value upon the retention of highly skilled employees:

- $\quad$ Research and development expense divided by net sales. We expect stronger sunset rules in high R\&D industries, since research spending requires firms to hire and retain technically advanced workers. 
- The level of voluntary worker turnover (sometimes called the "quit rate"), excluding layoffs, retirements and deaths, within each firm's industry as measured by the Bureau of Labor Statistics JOLTS survey between 2001 and 2006. Due to the costs of recruiting and training new workers, a high industry quit rate should be associated with stronger sunset rules.

- $\quad$ The firm's historical growth rate, measured as the compound annual growth rate of net sales in the five-year period 1999 to 2004. Fast-growing firms have a high demand for labor and should therefore have stronger sunset rules to bind workers to the company.

- A dummy variable for firms with corporate headquarters in the state of California. California business law places severe restrictions upon non-compete agreements, meaning that workers can change jobs more easily in that state than elsewhere in the U.S. ${ }^{12}$ We therefore expect California-based companies to have stronger sunset rules to counteract the state's liberal employment laws. The California dummy variable also would be expected to exhibit an association with strong sunset rules due to the state's dominant position in the high tech industry, with Silicon Valley companies having an ongoing need to hire and hold onto skilled workers.

- The Herfindahl Index, which measures the degree of competition within an industry. We construct the index at the three-digit SIC level using annual data for net sales, and it equals the sum of the squared market shares of each company in the industry. The index takes a high value when an industry has strategic interaction among a few large players and the cost of defections by key employees is potentially high.

Additional regression controls include firm size (the log of total assets), firm age (the log of years since the IPO, with no firm listed as more than 80 years old due to CRSP data limitations), industry dummy variables defined according to the 48 groupings of Fama and French, and the breadth of each company's option program, equal to the percentage of option awards made to employees other than the top five executive officers. Our measure of option breadth is calculated on a cumulative basis over a company's entire history on the ExecuComp

\footnotetext{
12 Many firms' option plans include non-compete language for workers who retire but wish to hold onto their options. These non-compete provisions generally forbid workers who retire from working for another firm in the same industry or taking other actions adverse to the company while an option remains unexercised. A retiree who wished to take a job elsewhere would therefore have to exercise his options before accepting the new position. However, such provisions would likely not apply in California due to Section 16600 of the California Business and Professions Code. For a discussion, see Akin, Gump, Strauss, Hauer \& Feld, "Check your noncompete clauses - California court gives employees a new basis to void employment agreements," Summer 2001, www.akingump.com/docs/publication/412.pdf.
} 
database, from 2004 to as far back to 1992, the database's first year of coverage. Our mean and median values of option breadth, 0.84 and 0.87 , are somewhat higher than those reported by Core and Guay (2001), 0.67 and 0.69, for the 1994 to 1996 period for a sample of companies across all ranges of the ExecuComp database, not just the large firms analyzed by us.

Our regression results appear in Tables 6 and 7. Table 6 presents estimates for the three dependent variables taken directly from firms' option plans: the weighted average time for options to vest, the time permitted to exercise options in retirement, and an indicator variable for the forfeiture of all unvested options at retirement. Table 7 presents estimates for two dependent variables that we calculate: the percentage of option value forfeited in each firm by a 65 -year-old executive who retires one year after receiving a new option, and an indicator variable for firms whose sunset rules impose greater financial penalties upon executives when they retire compared to when they die in office. In Tables 6 and 7 we show two sets of regression estimates for each dependent variable, both with and without industry dummy variables. Along with coefficient estimates for our main dependent variables, we tabulate coefficients for the software industry dummy variable, both because of the evident importance of human capital as an input in this industry, and also because the use of options for compensation by software firms has attracted enormous attention from both academics and business journalists.

Space constraints do not permit us to discuss all of the estimates in Tables 6 and 7, but we note patterns of statistically significant results that occur across many or most of the ten regressions. In general, sunset rules appear strongest in companies that are smaller, younger, and faster growing, as shown by estimates in the first three rows of both tables. These findings are broadly consistent with the idea that knowledge-based firms, with high needs to retain valuable 
human capital, have the strongest sunset rules, since such companies tend to be young, small, and fast-growing. More direct tests of this hypothesis are available from estimates in the subsequent rows of each table, and these generally lend further support to the golden handcuffs theory. The R\&D / sales variable has the expected sign in all ten regressions, though it is significant in only three models out of ten; the same uniform pattern of expected signs occurs with the Herfindahl index (significant five times in ten regressions), the California location dummy variable (significant six times out of ten), and the software industry dummy variable (significant two times out of five). Estimates for the California indicator variable weaken when industry dummy variables are included, indicating that the California variable is somewhat of a proxy for technology companies. Alone among our human capital variables, the industry quit rate exhibits erratic sign changes across models and is significant only once in ten models, though this significant estimate has the expected sign.

Three further patterns in Tables 6 and 7 appear important to us. First, the R\&D variable - often viewed by researchers as the leading measure of knowledge-intensive firms - exhibits statistical significance only in regressions that exclude industry dummy variables. This indicates that patterns in option plan design may be exhibit more variation at the industry level than across individual firms within an industry. Second, our measure of option plan breadth has little association with the strength of firms' sunset rules. This seems to imply that worker retention concerns, to the extent they influence option plan design, extend well beyond members of top management down into the ranks of middle and lower management. Third, we observe almost no statistically significant estimates in our regressions on the left of Table 6 with options' vesting periods as the dependent variable; only the historical sales growth variable has a 
significant estimate. Further, the overall F-test for the regression without industry dummy variables is not statistically significant and has a very low adjusted r-squared of 0.009 . Our failure to detect significant associations between firms' vesting schedules and most of our independent variables is the same outcome reached by Kole (1997, Table 4), who uses data from 1980 to investigate whether vesting periods are longer for firms with high values of R\&D but does not find significant results. Our results seem to indicate that vesting schedules are not as important to firms in designing their option plans as other parameters such as forfeiture or truncation provisions for executives who leave the company.

\section{Sunset rules and executive turnover}

Analysis above suggests that options' sunset rules are set by companies to help them retain valuable employees. In this section, we investigate whether direct evidence exists of a connection between sunset rules and actual rates of executive turnover.

Research into firms' rates of worker turnover is difficult, because no statistics are publicly reported about worker attrition, and it is not even clear that firms compile this data. Prior firm-level research into employee turnover has generally been limited to the five most highly paid officers of a firm as listed in the compensation section of the annual proxy statement; when an executive appears in the proxy statement one year and is omitted the next year, the convention is to assume that the executive has left the company. We adopt this convention as well, although we note that it will somewhat over-estimate actual turnover rates, because it is possible for executives to remain employed but see their position in the firm's compensation hierarchy fall so that they are no longer among the five most highly paid. 
We use the ExecuComp database to calculate turnover rates for top-five managers in each company. We record every individual listed in proxy statements from 2004 back to 1992, or as long as the company is covered by ExecuComp. We identify the executive's last year in the database as a turnover year (we reserve data from 2005 to determine turnover cases for 2004). We divide the number of turnover observations for each company by the total number of personyears covered by ExecuComp. As shown in Table 5, mean and median values for this turnover variable are 12.8 and 12.5 percent, respectively, substantially lower than the data for industry turnover rates for workers at all levels of the firm.

Table 8 presents regression analysis of firms' top management turnover rates as a function of stock option sunset rules. Our main explanatory variables, taken from the top rows of Table 5, are the weighted average time for a firm's option awards to vest, an indicator for the forfeiture of unvested options when workers retire, and the maximum time permitted to exercise options in retirement. Additional control variables include industry dummy variables, the cumulative stock return from 1992 to 2004, and the stock's volatility measured using monthly return data over the previous ten years. We do not include a relative measure of stock performance, such as the industry average return, since the regressions already include dummy variables for industries. When a firm is covered by ExecuComp for a shorter period than the standard interval of 1992 to 2004, we use a correspondingly shorter period for measuring the firm's cumulative stock return.

Estimates in the left column of Table 8 show insignificant association between executive turnover and variables measuring the sunset rules related to vesting, forfeiture, and truncation. Our control variables for stock returns and stock volatility are each strongly significant with the 
expected signs. We proceed to adjust our model to account for the endogeneity of the sunset rules. As shown by the analysis in Table 6 above, each firm's policy for the vesting, forfeiture and maturity of retirees' options is not exogenous but instead depends on the firm's size, age, industry, and to a certain extent, its need to retain skilled workers. To take account of this endogeneity, we re-estimate the turnover regression in Table 8 by replacing the retiree option maturity variable with its fitted value, using output from the OLS regression in the fourth column of Table 6. These two-stage estimates, shown in the second column of Table 8 , now indicate a positive estimate for the option maturity variable, significant at the 5 percent level. Similar estimations using fitted values of the vesting and forfeiture variables do not lead to significant reults.

We conclude that sunset rules for setting option maturities in retirement have important effects upon executive turnover. The point estimate in the right column implies that adding one year (or 12 months) of maturity to retirees' options would be associated with a 0.4 percentage point annual rise in the frequency of management turnover, compared to the unconditional mean of 12.8 percent.

A recent paper by Carter and Lynch (2004) uses an alternative measure of employee turnover based upon the cancellation rates of stock options as disclosed in footnotes to firms' annual Form 10-K filings. The authors assume that option cancellations are correlated with workers' departure rates from the firm, and they find that cancellations are reduced when a company reprices its options. We obtain data on option cancellations for all of the firms in our sample, and we find mean and median values for the option cancellation rate of 4.8 percent and 3.7 percent, respectively, numbers that are implausibly low as estimates of overall employee 
turnover. When we reestimate the regressions in Table 8 using this quantity as the dependent variable, all of the important explanatory variables' coefficients fail to have statistical significance.

\section{Sunset rules and the early exercise of employee options}

The magnitude and reasons for early exercise have emerged as probably the most controversial issue in valuing executive stock options. Past research indicates that employee stock options are exercised well before expiration, a pattern often attributed to individuals' risk aversion and/or liquidity needs. This result was first shown by Huddart and Lang (1996) and has been verified by more recent studies such as Bettis, Bizjak, and Lemmon (2005) and Brooks, Chance, and Cline (2006). Each of those studies finds that ten-year options are exercised, on average, between the fifth and sixth anniversaries after the award date. The leading valuation approach incorporating early exercise is the stopping state model introduced by Carpenter (1998), and accounting standards such as FAS 123R permit firms to make rudimentary adjustments to the Black-Scholes model to account for expected future patterns of early exercise.

None of the prior studies of early option exercise accounts for inter-firm variation in option sunset rules such as vesting, forfeiture, and truncation. As noted above in our introduction, summary statistics about executive turnover and option holdings suggest that most option exercises take place at or after an executive's date of departure from the company, meaning that sunset rules probably influence the timing of option exercises in important ways.

In this section we develop further the argument that early option exercise occurs partly because of firm-specific sunset rules. In some companies, sunset rules affect early exercise 
directly by truncating the lives of options held by employees who leave their firms and causing them to exercise earlier than they otherwise might. Vesting rules also affect early exercise in the other direction, by preventing active workers from exercising options as early as they might wish. Additionally, sunset rules indirectly cause data about option exercises to be censored, because the time periods during which former employees must report option exercises to the SEC often lapse well before the lives of the options they retain after leaving their firms. ${ }^{13}$ This censoring would tend to lead to over-sampling of companies with strict sunset rules that induce early option exercises before the end of the SEC's Form 4 filing requirements for ex-employees. These conjectures suggest that samples of Form 4 filings used as the basis for prior research may exaggerate the severity of early exercise, and that controlling for inter-firm variation in sunset rules may represent an opportunity to improve the precision of early exercise estimates. We present regressions in Table 9 that represent preliminary steps in such analysis.

For each company in our sample for which we have complete information about sunset rules, we download the full sample of option exercises between 2002 and 2004 that is available from the Thomson Financial database of Form 4 filings, which is the standard, comprehensive source used in recent academic studies. As indicated in Table 5, we find that the mean and

\footnotetext{
${ }^{13}$ Three separate SEC rules affect the obligations of former officers and directors to disclose stock transactions after leaving the firm. Rule 16a-2(a) provides the simple guideline, relevant for many insiders, that Form 4 filing requirements cease at the time an insider leaves. However, a major exception is that former insiders must file Form 4 for transactions occurring up to six months after an opposite transaction that occurred while they were still with the firm, as part of regulations against short-swing profits under Rule 16b-6. An exercise of options cannot trigger short-swing profit liability, according to Rule 16b-6(b), but many option exercises are accompanied by simultaneous sales of the stock acquired, and these dispositions must be reported on Form 4. In these cases, some insiders may choose to disclose their option exercises as part of the Form 4 filing for the sake of completeness. Finally, Rule 16a-3(f) indicates that for certain miscellaneous transactions, a former insider my omit filing Form 4 and instead file Form 5 within 45 days after the end of the company's fiscal year during which they leave. Form 5 is also required when an insider does not file a transaction on Form 4 in a timely way. Form 5, when filed, must include all of an executive's transactions during the fiscal year, so it is possible that some Form 5 filings report option exercises as late as one year plus 45 days after the insider leaves the company. We appreciate the help of securities law professors Stephen Choi and Joan Heminway in untangling these provisions.
} 
median time at which employees exercise options during this period is about 3.6 years prior to expiration. Surprisingly, these statistics indicate approximately one full year less early exercise than found in the three studies cited above. We believe the reason for this dramatic shortening of the early exercise phenomenon is quite simple: our data come from a period of stagnation in the U.S. stock markets, when options were moving into-the-money at much slower rates than during the market boom years of the 1980s and 1990s. All past studies of early exercise were largely based upon data from periods of stock market run-ups, during which most option holders would have lost little value by exercising deep-in-the-money options years before expiration. Therefore, simple univariate data strongly suggest that early option exercise is a path-dependent outcome, and that the patterns of very early option exercises in the 1980s and 1990s aren't likely to continue without a recurrence of the Reagan and Clinton era bull markets.

We next calculate the percentage of each company's total option exercises between 2002 and 2004 that appear on the Thomson database. To determine this percentage, we divide the number of exercises reported by Thomson into each company's total option exercises, which is reported in Form 10-K footnotes each year and was provided to us by Equilar, Inc. As shown by Table 5, the mean and median values for the Thomson database's coverage frequency are 16.5 percent and 13.0 percent, respectively, meaning that the vast majority of optionees are not required to file Form 4 when they exercise, and their exercise behavior is not accounted for by early exercise research. Presumably most of these non-filers are lower level employees, since Form 4 is generally only filed by officers and directors.

Our regression models in Table 9 study the reported times of early option exercises for our sample firms, as well as the fraction of each firm's total option exercises between 2002 and 
2004 that are captured by the Thomson database. Each dependent variable is measured at the firm level on a cumulative basis from 2002 to 2004 . Table 9's explanatory variables include our three main sunset rules related to vesting, forfeiture, and truncation of options; stock volatility; the three year return on each firm's stock from fiscal 2002 through fiscal 2004; a dummy variable for firms paying zero dividends; our measure of option plan breadth, the extent to which options are awarded to employees other than the top five executives; an indicator for firms that make reload option awards; and dummy variables for industries and fiscal year-end months. The variables for stock volatility, stock return, and dividend payments are found by Bettis et al. (2005) to be especially important predictors of early exercise. Reload options will almost certainly be exercised earlier than other options, since a reload exercise causes the firm to award new options with higher exercise prices but the same expiration dates as those exercised. Indicators for fiscal year-end months are potentially important because changes in Form 4 filing requirements took place in August 2002 and June 2003 pursuant to the Sarbanes-Oxley Act, ${ }^{14}$ potentially affecting the production of raw data aggregated in the Thomson database.

Our regression models of early exercise in the first two columns of Table 9 show, in accord with earlier studies, that options are exercised earlier when the underlying stock price rises and when volatility is high. In addition, we find that a firm's vesting schedule and its use of reload options are both highly significant predictors of early exercise. If the weighted average time for options to vest increases by one year, the tendency for optionees to exercise early declines by about 0.4 years or five months. Firms awarding reload options tend to experience

\footnotetext{
14 Beginning on August 29, 2002, option exercises had to be filed with the SEC within 48 hours, compared to the prior deadline of the $10^{\text {th }}$ day of the next calendar month. After June 30, 2003, these filings had to be made electronically via company Internet sites.
} 
option exercises nearly one year earlier than other firms. We do not find evidence of a significantly negative association, as we might have expected, between early exercise and the amount of option life retained by retirees. Together, these results suggest that early exercise pattens are highly sensitive to the rules of individual company plans. However, all of these estimates must be interpreted with caution, because of the evidence of data censoring that is indicated by estimates in the third and fourth columns of Table 9 .

Results on the right side of Table 9 indicate that the frequency of Form 4 filings depends strongly upon whether retiring option holders are allowed to keep their options alive for more than one year. We construct this independent variable based upon a one year cutoff because as discussed above, the SEC's Form 4 and Form 5 filing requirements apply to a former company officer or director for, at most, one year after the individual exits the company. When retiring optionees can hold their options longer than one year, Table 9's regression estimates indicate that the rate of Form 4 filings drops by 3 to 4 percentage points out of the firm's total number of option exercises. Since the mean and median values for this variable are 16.5 percent and 13.0 percent, respectively, a drop of 3 to 4 percentage points represents a meaningful change in the amount of information available to researchers. It seems logical that the large majority of the excluded data should represent cases in which employees hold their options for longer periods, implying that calculations of exercise times from the surviving data will be biased downward.

Other significant coefficient estimates in the right columns of Table 9 occur for variables for the firm's stock return, dividend payout, and the breadth of its option awards. The positive association between the firm's stock performance and the percentage of option exercises recorded on the database probably occurs for two reasons: when stock prices rise, retiring 
executives are more likely to exercise within the required filing window for Form 4, and executive turnover itself is also likely to be lower. The positive association between firms paying zero dividends and the presence of Form 4 filings on the database is something of a surprise, since low dividend payments generally imply later option exercises and perhaps also a higher rate of executive turnover. The negative association between the database's coverage of option exercises and each firm's option plan breadth is quite intuitive, since Form 4 is filed only by top officers and directors.

We conclude that firms' sunset rules have important effects upon patterns of option exercises, both directly, by limiting executives' flexibility to choose exercise dates, and indirectly, by affecting the amount and nature of data about exercise timing that becomes available for analysis. We end this section with several observations about how sunset rules, properly accounted for, might enhance the findings of related prior research.

In addition to studies of the timing of option exercises, a parallel literature has considered whether managers' option exercises signal information that can forecast the future path of stock prices; the leading studies are Carpenter and Remmers (2001) and Brooks, Chance, and Cline (2006). Accounting for firms' sunset rules could improve the power of these studies; one could drop from the samples option exercises that appear to be caused by the operation of firms' sunset regulations and analyze the only the remaining observations, which are more likely to be affected by managerial discretion over the exercise date.

Stopping state models of early exercise could be usefully augmented by including firms' sunset rules as an input. These models are binomial algorithms in which an option's life is modeled as a series of nodes. At each node, the stock price can either rise or fall, and the option 
holder also faces an exogenous probability of leaving the firm (the "stopping rate"). If he does leave, he is forced either to exercise or forfeit the option at once. For some firms, an immediate exercise requirement resembles the actual sunset rule, but for other firms this stylization is inappropriate, as managers are sometimes permitted to retain unexercised options for many years. In using real-world data to calibrate stopping state models (see Carpenter (1998) and Bettis et al. (2005)), researchers could improve the precision of the model's estimates by incorporating each firm's actual sunset rules so that immediate exercise is not required of all managers who reach the stopping state. Moreover, empirical samples should be carefully drawn to avoid over-representation of observations from firms with harsh sunset rules, as discussed above. Each of these changes, if properly implemented, would seem to imply higher executive option values as outcomes from stopping state estimations.

\section{Sunset rules and the apparent award date value of executive options}

Studies of executive turnover suggest that a large majority of managers should expect to leave their companies at or before age $65 .{ }^{15}$ Many firms' defined benefit pension plans use age 65 (or an earlier age) as the time at which a manager can retire and draw his full pension, and age 65 is also when U.S. employment law permits firms to impose mandatory retirement rules for top executives. If a manager expects to leave his company at or before age 65 , this expected time of departure should affect the apparent value to him of new stock option awards, since he

\footnotetext{
15 The clearest demonstration of this appears in Table 1 of Coughlan and Schmidt (1985), the first published study of CEO turnover. That table shows that the unconditional turnover frequency for CEOs spikes upward at ages 63 , 64, and 65, and that less than 10 percent of CEOs in office at any given time are over 65 . More recent studies feature similar statistics; for example, Huson, Malatesta and Parrino (2004) show that the mean age for departing CEOs is 61.6 years, and the median is 63, with a standard deviation of 5.85 years. Hayes and Schaefer (1999) report mean ages of 61 for CEOs who die in office and 51 for CEOs who resign to take the top job at other firms.
} 
would know in advance that the options' sunset rules would operate at that time.

Figure III uses a stylized example to illustrate how typical sunset rules would affect the apparent value of new options awarded to managers of different ages, if we assume that all managers expect to retire at age 65 . For purposes of the figure, we make a set of generic assumptions about the characteristics of new options. We assume that all options have an exercise price of $\$ 25.00$ per share, which is also assumed to be the underlying stock price on the award date. The dividend yield is assumed to be 0.015 , volatility is assumed to equal 0.30 , and the risk-free rate is fixed at 0.045 . We also assume that the options vest ratably over four years and expire after ten years unless the manager leaves the firm, in which case they expire three years after his departure.

Figure III shows that these generic options, if awarded to CEOs aged 58 or less, are worth just under $\$ 10.00$ each according to the Black-Scholes formula. At ages 59 and greater, the executive perceives these options to have an expiration date of less than 10 years, since we assume that the executive will retire at age 65 and the option will lapse three years after that. Figure III shows the effect of this shortened expiration in two cases: if the executive is allowed to retain unvested options when he retires (the top line), and if he is instead required to forfeit unvested options (the lower line). In the latter case, the figure shows that the joint impact of forfeiture and shortened maturity can be severe, reducing the apparent value of a new option award by more than 80 percent for CEOs aged 64 or higher.

We repeat this analysis using actual data for all options awarded to the CEOs of our sample firms in 2004. We record the age of each CEO and assume that he will retire at age 65 or, if already past 65 , then one year after the award. We recognize that these retirement 
assumptions are stylized and do not reflect the possibility of retirement dates depending endogenously upon sunset rules for compensation. For these reasons, our results should be interpreted as suggestive rather than precise estimates of the value consequences of sunset rules, though we believe that mandatory retirement rules which are binding in many firms make our simulations based upon age 65 very relevant. ${ }^{16}$

For each actual CEO option award award, we ascertain how much, if any, would not have vested by the expected retirement date of age 65, and we apply the company's sunset rules for forfeiture and/or accelerated or pro-rata vesting, as appropriate. We also assume that the options' life is expected to change at each CEO's retirement, again using the company's sunset rules, and we use these rules to calculate shortened expiration dates for each CEO's options whenever such an adjustment is relevant.

Table 10 presents the results of this analysis for three subsamples of CEOs: those aged 61-62, 63-64, and 65 or above. The table shows apparent option award values for these subsamples before and after application of each firm's sunset rules. The data indicate that option award values should be adjusted downward for 49 percent of the CEOs in the first age range, 79 percent of those in the second range, and 82 percent of those who are already 65 or older. The magnitude of these adjustments is significant: the values of options awarded to CEOs aged 61-62 should be reduced by a mean of 13 percent, while the mean reductions for CEOs in the two older

\footnotetext{
${ }^{16}$ Research into CEO separation agreements indicates that, although boards of directors have the flexibility to waive sunset rules, this happens infrequently. Yermack (2006) presents data indicating that standard sunset rules for equity compensation are altered for only 8 percent of CEOs retiring voluntarily and 16 percent of CEOs who are dismissed, and some of these alterations relate only to restricted stock and not options. An interesting qualification to this result is that many exiting CEOs remain as participants in their firms' equity compensation plans and keep their options alive by continuing as members of their boards of directors after leaving the CEO post. However, post-CEO board service is relatively rare for dismissed CEOs and is generally of short tenure even in cases of friendly CEO succession.
} 
age groups are 44 percent and 53 percent, respectively. Because option awards comprise roughly half of total CEO compensation for our sample firms, the impact of these reductions is extremely important in the context of the CEOs' overall pay packages. For CEOs age 65 or older, for instance, mean total pay falls by one-fourth after option values are reduced to take account of sunset rules.

Two qualifications are important for perspective on our conclusions about option values. First, many approaches to valuing executive options, such as the calculations used in ExecuComp and those permitted by the FAS 123R accounting rules, use a reduced expected option life to reflect the possibility of early exercise. If these reductions were imposed acrossthe-board, the dollar-value reductions calculated above would diminish. However, one of the implications of our data appears to be that reductions in expected option life should vary according to the age of the optionee and not be applied in a uniform fashion. Second, the differences in option value that we find do not carry over as dramatically to calculations of incentives, as measured by the deltas of options or their change in value with respect to the underlying stock price, since option deltas are not particularly sensitive to changes in expected option life.

\section{Conclusions}

This paper investigates sunset provisions of executive stock options, showing that when managers leave their firms, their options become subject to a variety rules related to options' exercisability and expiration. These rules vary considerably across companies. Some firms with lenient sunset provisions permit exiting managers to retain their options for many years and 
provide for continuing or even accelerated vesting of options when managers exit the company. In contrast, other firms have less lenient regulations that lead to shortened option lives and forfeiture of unvested awards.

Along with our documentation of the variety and magnitude of these sunset provisions, we develop a number of empirical results. We find that the strength of sunset rules varies company-by-company in relation to each firm's size, age, skilled labor demand, and the degree of competitive rivalry within an industry. We document a positive association between the leniency of firms' sunset provisions and the rate at which top managers exit the firm. We find that sunset rules, particularly those related to vesting, significantly influence patterns of early option exercise, while also affecting the extent to which data about early exercise is disclosed to via SEC filings. Finally, we use simulations to document the impact of sunset rules upon the apparent values of new stock options when awarded to managers who expect to retire before the options expire; our results imply that estimates of option values and total compensation for older CEOs should be discounted substantially. 


\section{References}

Ammann, Manuel, and Ralf Seiz, 2004, Valuing employee stock options: Does the model matter? Financial Analysts Journal 60:5, 21-37.

Bettis, J. Carr, John M. Bizjak, and Michael L. Lemmon, 2005, Exercise behavior, valuation, and the incentive effects of employee stock options, Journal of Financial Economics 76, 445-470.

Brooks, Robert, Don M. Chance, and Brandon N. Cline, 2006, Private information and the exercise of executive stock options, unpublished manuscript, University of Alabama.

Bulow, Jeremy, and John B. Shoven, 2004, Accounting for stock options, unpublished manuscript, Stanford University.

Carpenter, Jennifer N., 1998, The exercise and valuation of executive stock options, Journal of Financial Economics 48, 127-158.

Carpenter, Jennifer N., and Barbara Remmers, 2001, Executive stock option exercises and inside information, Journal of Business 74, 513-534.

Carter, Mary Ellen, and Luann J. Lynch, 2004, The effect of stock option repricing on employee turnover, Journal of Accounting and Economics 37, 91-112.

Chen, Mark A., 2004, Executive option repricing, incentives, and retention, Journal of Finance 59, 1167-1199.

Core, John E., and Wayne R. Guay, 2001, Stock option plans for non-executive employees, Journal of Financial Economics 61, 253-287.

Coughlan, Anne T., and Ronald M. Schmidt, 1985, Executive compensation, management turnover, and firm performance: An empirical investigation, Journal of Accounting and Economics 7, 43-66.

Dechow, Patricia M., and Richard G. Sloan, 1991, Executive incentives and the horizon problem, Journal of Accounting and Economics 14, 51-89.

Hayes, Rachel M., and Scott Schaefer, 1999, How much are differences in managerial ability worth? Journal of Accounting and Economics 27, 125-148.

Huddart, Steven, and Mark Lang, 1996, Employee stock option exercises: An empirical analysis, Journal of Accounting and Economics 21, 5-43.

Huson, Mark R., Paul H. Malatesta, and Robert Parrino, 2004, Managerial succession and firm performance, Journal of Financial Economics 74, 237-275. 
Kole, Stacey R., 1997, The complexity of compensation contracts, Journal of Financial Economics 43, 79-104.

Pasternack, Daniel, and Matts Rosenberg, 2003, What determines stock option contract design? Unpublished manuscript, Swedish School of Economics and Business Administration.

Sautner, Zacharias, and Martin Weber, 2006, Corporate governance and the design of stock option programs, unpublished manuscript, Mannheim University.

Smith, Clifford W., Jr., and Ross L. Watts, 1992, The investment opportunity set and corporate financing, dividend, and compensation policies, Journal of Financial Economics 32, 263-292.

Yermack, David, 2006, Golden handshakes: Separation pay for retired and dismissed CEOs, Journal of Accounting and Economics 41, 237-256. 


\section{Table 1 \\ Value of adjustments to option terms when managers retire}

The table shows the value consequences of adjustments to stock option awards when managers retire from two companies, using the hypothetical example of a 64-year-old executive who receives new options when planning to retire one year later at age 65. Under the option plans of each company, a new award vests in four annual tranches, and each firm has different rules for whether the tranches are subject to the possibility of forfeiture and/or reduced time to expiration when the optionee retires. The first area of the table shows a "base case" option award that has no forfeiture and no shortened expiration when the optionee retires. The second area of the table shows data for Time Warner, which truncates all option tranches to a maximum of 5 years from an optionee's retirement date but requires no forfeiture of unvested options. The third area of the table shows data for Viacom, which requires forfeiture of three out of the four award tranches if the optionee retires, while shortening the reamaining life of the fourth tranche to a maximum of 3 years. Value calculations, which use the Black-Scholes method, are based on the same set of input parameters for both companies: award date stock price and exercise price of $\$ 25.00$, volatility of 0.30 , risk-free rate of 0.45 , and dividend rate of 0.015 .

\section{Base Case}

Tranche 1

Tranche 2

Tranche 3

Tranche 4

Total

Time Warner (Figure 1a)

Tranche 1

Tranche 2

Tranche 3

Tranche 4

Total

Value lost relative to Base Case

Viacom (Figure 1b)

Tranche 1

Tranche 2

Tranche 3

Tranche 4

Total

Value lost relative to Base Case

\begin{tabular}{|c|c|c|}
\hline Original T & Adjusted T & Value \\
\hline 10 & 10 & $\$ 9.93$ \\
\hline 10 & 10 & $\$ 9.93$ \\
\hline 10 & 10 & $\$ 9.93$ \\
\hline 10 & 10 & $\$ 9.93$ \\
\hline & & $\$ 39.72$ \\
\hline
\end{tabular}

\begin{tabular}{cccc}
$\frac{\text { Original T }}{10}$ & $\frac{\text { Adjusted T }}{n n n}$ & & $\frac{\text { Value }}{\$ 8.06}$ \\
10 & 6 & & $\$ 8.06$ \\
10 & 6 & \\
10 & 6 & $\$ 8.06$ \\
& & $\$ 8.06$ \\
\hline 32.24
\end{tabular}

$-16 \%$

\begin{tabular}{|c|c|c|}
\hline Original T & Adjusted T & Value \\
\hline 10 & 4 & $\$ \$ 6.67$ \\
\hline 10 & forfeited & $\$ 0$ \\
\hline 10 & forfeited & $\$ 0$ \\
\hline \multirow[t]{3}{*}{10} & forfeited & $\$ 0$ \\
\hline & & $\$ 6.67$ \\
\hline & & $-83 \%$ \\
\hline
\end{tabular}




\section{Table 2 \\ Sample selection}

Sample selection for a study of stock option plans in effect for the S\&P 500 firms as of Fall 2005. Stock option plans are available as attachments to firms' 10-K, 10-Q, Proxy or 8-K SEC filings. Some firms provide additional detail about option awards in annual term sheets that are also filed as attachments to these documents. Companies are excluded from the study if they do not have an active stock option plan on file or their plan does not include adequate detail about the treatment of options when employees leave the company.

Firms excluded:

No active plan for awarding stock options

Newly public, no stock option plan filed with SEC

Option plan filed, with incomplete data

Sample for analysis 


\section{Table 3}

\section{Lives of executive stock options}

Summary statistics about the lives of executive stock options, based upon an analysis of 389 S\&P 500 firms' option plans in effect during Fall 2005. Panel A shows the distribution of option expirations across sample firms as of the award date. Panel B shows sample statistics about the option life retained when executives leave their firms due to either retirement, resignation, or death. In most companies, age and service criteria are used to differentiate cases of retirement from resignations. Data in Panel B represent maximum values, since executives are generally not permitted to extend the lives of options beyond their original expiration dates.

\section{Panel A: Distribution of executive stock option expirations at award date}

$\begin{array}{ccc}\begin{array}{c}\text { Option } \\ \text { expiration }\end{array} & \begin{array}{c}\text { Number } \\ \text { of firms }\end{array} & \begin{array}{r}\text { Percentage } \\ \text { of sample }\end{array} \\ \text { 4 years } & 1 & 0.3 \% \\ \text { 5 years } & 7 & 1.8 \% \\ 6 \text { years } & 5 & 1.3 \% \\ 7 \text { years } & 30 & 7.7 \% \\ 8 \text { years } & 7 & 1.8 \% \\ 9 \text { years } & 1 & 0.3 \% \\ \text { 10 years } & 338 & 86.9 \%\end{array}$

Mean $=9.57$

Std. Dev. $=1.16$

\section{Panel B: Executive stock option life (maximum, in years)} retained by executives who leave their firms

\begin{tabular}{|c|c|c|c|c|c|c|c|c|c|}
\hline \multirow[b]{2}{*}{ Reason for leaving firm } & \multirow[b]{2}{*}{ Mean } & \multirow[b]{2}{*}{$\begin{array}{l}\text { Std. } \\
\text { Dev. }\end{array}$} & \multicolumn{7}{|c|}{ Percentiles of distribution } \\
\hline & & & Min & $10^{\text {th }}$ & $25^{\text {th }}$ & Med & $75^{\text {th }}$ & $90^{\text {th }}$ & $\operatorname{Max}$ \\
\hline Retirement & 4.43 & 3.71 & 0 & 0.25 & 1 & 3 & 10 & 10 & 10 \\
\hline Resignation & 0.40 & 1.19 & 0 & 0 & 0.08 & 0.25 & 0.25 & 5 & 10 \\
\hline Death in office & 3.15 & 3.17 & 0 & 1 & 1 & 1 & 5 & 10 & 10 \\
\hline
\end{tabular}




\section{Table 4}

\section{Vesting policies for executive stock options}

Summary statistics about the vesting of executive stock options, based upon an analysis of 389 S\&P 500 firms' option plans in effect during Fall 2005. Panel A shows the vesting time in years for at least half of an award to vest, an entire award to vest, and the weighted average time for the entire award to vest. Panel B tabulates firms' policies for the treatment of unvested options when executives leave their firms due to either retirement, resignation, or death. In most companies, age and service criteria are used to differentiate cases of retirement from resignations. Pro rata vesting refers to partial vesting of options based upon the fraction of the full vesting period that an executive has served.

\section{Panel A: Vesting periods (in years) from date of award}

\begin{tabular}{|c|c|c|c|c|c|c|c|c|c|}
\hline \multirow[b]{2}{*}{ Amount of award vested } & \multirow[b]{2}{*}{ Mean } & \multirow[b]{2}{*}{$\begin{array}{l}\text { Std. } \\
\text { Dev. }\end{array}$} & \multicolumn{7}{|c|}{ Percentiles of distribution } \\
\hline & & & Min & $10^{\text {th }}$ & $25^{\text {th }}$ & Med & $75^{\text {th }}$ & $90^{\text {th }}$ & Max \\
\hline Half of award & 2.22 & 0.70 & 0 & 2 & 2 & 2 & 2 & 3 & 6 \\
\hline Entire award & 3.59 & 1.07 & 0 & 3 & 3 & 3 & 4 & 5 & 10 \\
\hline Weighted average & 2.38 & 0.67 & 0 & 2 & 2 & 2.5 & 2.5 & 3 & 6 \\
\hline
\end{tabular}

\section{Panel B: Treatment of unvested options for executives who leave their firms (number of firms, percent of sample)}

\begin{tabular}{lrrrrrr} 
& \multicolumn{1}{c}{ Retirement } & Resignation & Death in office \\
& 130 & $33.4 \%$ & 7 & $1.8 \%$ & 217 & $55.8 \%$ \\
Full immediate vesting & 67 & $17.2 \%$ & 7 & $1.8 \%$ & 19 & $4.9 \%$ \\
Continue original vesting schedule & 12 & $3.1 \%$ & 3 & $0.8 \%$ & 8 & $2.1 \%$ \\
Pro rata immediate vesting & 9 & $2.3 \%$ & & & 9 & $2.3 \%$ \\
Other partial vesting & & & & & & \\
& 171 & $44.0 \%$ & 372 & $95.6 \%$ & 136 & $35.0 \%$
\end{tabular}

Panel C: Mean option life retained by certain subsamples of executives who leave their firms

$\begin{array}{lccc}\text { Treatment of unvested options } & \text { Retirement } & \text { Resignation } & \text { Death in office } \\ \text { Full immediate vesting } & 5.37 \text { years } & 5.57 \text { years } & 3.49 \text { years } \\ \text { Forfeited } & 2.52 \text { years } & 0.29 \text { years } & 1.95 \text { years }\end{array}$




\section{Table 5 \\ Descriptive statistics for variables}

Descriptive statistics for key variables used in regression analysis. The variable measuring option value lost at retirement is based upon a hypothetical executive option that is awarded at-the-money to a 65-year-old. Calculations of these option value losses are performed using the Black-Scholes method and assume a stock price and exercise price of $\$ 25.00$, volatility of 0.30 , risk-free rate of 0.045 , dividend rate of 0.015 , and each company's policies for vesting, forfeiture and truncation. Company volatility data is calculated based upon up to ten years of monthly stock returns for each firm. The Herfindahl index is based upon firms' sales data and is tabulated at the three-digit SIC level. Data on vesting and forfeiture terms for stock options are collected from option plan documents of each company. Option plan breadth is the total fraction of each firm's options awarded to persons other than its top five executives, based on the company's entire history on the ExecuComp database. The variable measuring years since the IPO date is capped at 80 years, the oldest age available on the CRSP database. The industry quit rate is tabulated from Bureau of Labor Statistics survey data. The California location indicator equals one if the firm's headquarters is located in that state. The fraction of the firm's option exercises reported on the Form 4 database equals the options exercises reported on the Thomson Financial insider trading database divided by the firm's total exercises as reported in footnotes to annual Form 10-K filings. The mean time at which options are exercised relative to the expiration date is calculated separately for each firm based on data reported on the Thomson database, and the table reports descriptive statistics for these within-firm means. 
Time for option awards to vest (weighted average, months)

Time to exercise options in retirement (maximum, months)

Forfeiture of all unvested options at retirement (indicator)

Option value lost at retirement (percentage)

Retirement treated same or worse than death (indicator)

Option plan breadth (pct. of awards beyond top five executives)

Annual turnover rate among firm's top five executives, 1992-2004

Firm size (log of total assets)

Years since firm's IPO

Research \& development expense / net sales

Herfindahl index

Stock return, three years, 2002-04

Sales growth rate, annualized, 1999-2004

Stock volatility

Software industry indicator

California location indicator

Industry voluntary quit rate, 2001-05

Fraction of firm's exercises reported on Form 4 database, 2002-04

Mean time of option exercises, years prior to expiration, 2002-04

Firm awards reload options (indicator)

Firm pays zero dividends in 2004 (indicator)

\begin{tabular}{|c|c|c|c|c|c|c|}
\hline \multirow[b]{2}{*}{ Mean } & \multirow[b]{2}{*}{$\begin{array}{l}\text { Std. } \\
\text { Dev. }\end{array}$} & \multicolumn{5}{|c|}{ Percentiles } \\
\hline & & $10^{\text {th }}$ & $25^{\text {th }}$ & Med & $75^{\text {th }}$ & $90^{\text {th }}$ \\
\hline 28.6 & 8.1 & 24 & 24 & 30 & 30 & 36 \\
\hline 52.9 & 44.5 & 3 & 12 & 36 & 120 & 120 \\
\hline 0.44 & 0.50 & 0 & 0 & 0 & 1 & 1 \\
\hline $53.5 \%$ & $38.0 \%$ & 0 & $22.3 \%$ & $65.7 \%$ & $91.4 \%$ & $96.7 \%$ \\
\hline 0.36 & 0.48 & 0 & 0 & 0 & 1 & 1 \\
\hline 0.84 & 0.11 & 0.70 & 0.79 & 0.87 & 0.91 & 0.95 \\
\hline $12.8 \%$ & $4.8 \%$ & $6.7 \%$ & $9.8 \%$ & $12.5 \%$ & $15.8 \%$ & $18.4 \%$ \\
\hline 9.34 & 1.39 & 7.74 & 8.24 & 9.19 & 10.23 & 11.21 \\
\hline 34.9 & 21.7 & 10 & 17 & 33 & 44 & 76 \\
\hline 0.038 & 0.079 & 0 & 0 & 0 & 0.036 & 0.145 \\
\hline 0.156 & 0.160 & 0.027 & 0.056 & 0.102 & 0.191 & 0.354 \\
\hline 0.076 & 0.155 & -0.102 & -0.007 & 0.084 & 0.169 & 0.253 \\
\hline 0.087 & 0.106 & -0.025 & 0.022 & 0.070 & 0.131 & 0.230 \\
\hline 0.379 & 0.158 & 0.235 & 0.270 & 0.331 & 0.438 & 0.615 \\
\hline 0.054 & 0.220 & 0 & 0 & 0 & 0 & 0 \\
\hline 0.147 & 0.355 & 0 & 0 & 0 & 0 & 1 \\
\hline 0.169 & 0.066 & 0.131 & 0.138 & 0.150 & 0.160 & 0.239 \\
\hline 0.165 & 0.140 & 0.026 & 0.063 & 0.130 & 0.229 & 0.351 \\
\hline 3.68 & 2.00 & 0.93 & 2.01 & 3.62 & 5.19 & 6.30 \\
\hline 0.090 & 0.287 & 0 & 0 & 0 & 0 & 0 \\
\hline 0.243 & 0.429 & 0 & 0 & 0 & 0 & 1 \\
\hline
\end{tabular}




\section{Table 6}

\section{Cross-sectional determinants of option plan sunset rules}

Regression estimates for models of various regulations contained in company stock option plans. The dependent variable in the first two columns equals the weighted average time for a company's stock options to vest. The third and fourth column's dependent variable equals the maximum time permitted for a retiring employee to exercise vested stock options. In the fifth and sixth columns, the dependent variable is a binary indicator that equals one if all unvested options are forfeited when an executive retires. The variable measuring years since the IPO date is capped at 80 years, the oldest age available on the CRSP database. The industry quit rate is computed from Bureau of Labor Statistics data. The California indicator equals one if the firm's corporate headquarters are located in that state. Standard errors appear in parentheses below each coefficient estimate.

\begin{tabular}{|c|c|c|c|c|c|c|}
\hline \multirow{3}{*}{$\begin{array}{l}\text { Estimation } \\
\text { Firm size (log of total assets) }\end{array}$} & \multicolumn{2}{|c|}{$\begin{array}{l}\text { Average time for } \\
\text { new options to vest } \\
\text { (months) }\end{array}$} & \multicolumn{2}{|c|}{$\begin{array}{l}\text { Time to exercise in } \\
\text { retirement } \times 10^{-2} \\
\text { (maximum, months) }\end{array}$} & \multicolumn{2}{|c|}{$\begin{array}{l}\text { All unvested options } \\
\text { forfeited at retirement } \\
\qquad(0,1)\end{array}$} \\
\hline & \multicolumn{2}{|c|}{ OLS } & \multicolumn{2}{|c|}{ OLS } & \multicolumn{2}{|c|}{ Logit } \\
\hline & $\begin{array}{c}0.34 \\
(0.34)\end{array}$ & $\begin{array}{c}0.49 \\
(0.43)\end{array}$ & $\begin{array}{l}0.06^{\mathrm{a}} \\
(0.02)\end{array}$ & $\begin{array}{r}0.09^{\mathrm{a}} \\
(0.02)\end{array}$ & $\begin{array}{l}-0.20^{\mathrm{b}} \\
(0.09)\end{array}$ & $\begin{array}{l}-0.18 \\
(0.13)\end{array}$ \\
\hline Firm age (log of years since IPO) & $\begin{array}{l}-0.42 \\
(0.63)\end{array}$ & $\begin{array}{l}-0.43 \\
(0.78)\end{array}$ & $\begin{array}{l}0.11^{\mathrm{a}} \\
(0.03)\end{array}$ & $\begin{array}{l}0.07^{\mathrm{b}} \\
(0.04)\end{array}$ & $\begin{array}{l}-0.43^{a} \\
(0.16)\end{array}$ & $\begin{array}{l}-0.52^{\mathrm{b}} \\
(0.21)\end{array}$ \\
\hline Sales growth (five year CAGR) & $\begin{array}{l}7.66^{\mathrm{c}} \\
(4.11)\end{array}$ & $\begin{array}{l}10.98^{\mathrm{b}} \\
(5.03)\end{array}$ & $\begin{array}{l}-0.36^{\mathrm{c}} \\
(0.20)\end{array}$ & $\begin{array}{l}-0.49^{\mathrm{b}} \\
(0.22)\end{array}$ & $\begin{array}{c}1.09 \\
(1.12)\end{array}$ & $\begin{array}{c}1.53 \\
(1.38)\end{array}$ \\
\hline R\&D / Sales & $\begin{array}{c}7.64 \\
(7.64)\end{array}$ & $\begin{array}{l}2.28 \\
(9.79)\end{array}$ & $\begin{array}{l}-0.20 \\
(0.37)\end{array}$ & $\begin{array}{l}-0.40 \\
(0.45)\end{array}$ & $\begin{array}{l}4.70^{\mathrm{b}} \\
(2.34)\end{array}$ & $\begin{array}{c}1.81 \\
(3.04)\end{array}$ \\
\hline Herfindahl Index & $\begin{array}{c}0.22 \\
(2.88)\end{array}$ & $\begin{array}{c}1.60 \\
(3.75)\end{array}$ & $\begin{array}{l}-0.04 \\
(0.13)\end{array}$ & $\begin{array}{l}-0.15 \\
(0.17)\end{array}$ & $\begin{array}{l}1.22^{\mathrm{c}} \\
(0.70)\end{array}$ & $\begin{array}{l}1.95^{\mathrm{b}} \\
(0.94)\end{array}$ \\
\hline $\begin{array}{l}\text { Breadth of option plan (pct. of } \\
\text { awards beyond top five execs.) }\end{array}$ & $\begin{array}{l}10.71 \\
(8.17)\end{array}$ & $\begin{array}{c}5.24 \\
(5.03)\end{array}$ & $\begin{array}{c}0.16 \\
(0.21)\end{array}$ & $\begin{array}{c}0.32 \\
(0.23)\end{array}$ & $\begin{array}{l}-1.56 \\
(1.12)\end{array}$ & $\begin{array}{l}-1.98 \\
(1.35)\end{array}$ \\
\hline Industry quit rate & $\begin{array}{c}8.55 \\
(6.75)\end{array}$ & $\begin{array}{l}-42.36 \\
(35.29)\end{array}$ & $\begin{array}{l}-0.64^{\mathrm{b}} \\
(0.33)\end{array}$ & $\begin{array}{l}1.10 \\
(1.51)\end{array}$ & $\begin{array}{l}-0.09 \\
(1.70)\end{array}$ & $\begin{array}{l}-1.88 \\
(4.25)\end{array}$ \\
\hline $\begin{array}{l}\text { California location } \\
\text { (indicator) }\end{array}$ & $\begin{array}{l}-2.07 \\
(1.39)\end{array}$ & $\begin{array}{l}-1.89 \\
(1.51)\end{array}$ & $\begin{array}{l}-0.29^{a} \\
(0.06)\end{array}$ & $\begin{array}{l}-0.22^{\mathrm{a}} \\
(0.07)\end{array}$ & $\begin{array}{l}0.81^{\mathrm{b}} \\
(0.35)\end{array}$ & $\begin{array}{c}0.64 \\
(0.39)\end{array}$ \\
\hline $\begin{array}{l}\text { Software industry } \\
\text { (indicator) }\end{array}$ & & $\begin{array}{c}1.08 \\
(6.15)\end{array}$ & & $\begin{array}{l}-0.14 \\
(0.22)\end{array}$ & & $\begin{array}{l}3.39^{\mathrm{a}} \\
(0.83)\end{array}$ \\
\hline Observations & 357 & 357 & 387 & 387 & 387 & 387 \\
\hline Industry indicators (Fama-French) & No & Yes & No & Yes & No & Yes \\
\hline Adjusted $\mathrm{R}^{2}$ & 0.009 & 0.041 & 0.188 & 0.297 & & \\
\hline F or Likelihood Ratio statistic & 1.42 & $1.30^{\mathrm{c}}$ & $12.16^{\mathrm{a}}$ & $4.27^{\mathrm{a}}$ & $48.99^{\mathrm{a}}$ & $91.98^{\mathrm{a}}$ \\
\hline
\end{tabular}

Significant at $1 \%(\mathrm{a}), 5 \%(\mathrm{~b})$, and $10 \%$ (c) levels. 


\section{Table 7}

\section{Regression estimates of strength of option plan sunset rules}

Regression estimates of the strength of various sunset regulations in company stock option plans. The dependent variable in the left two columns equals the percentage of option award value lost at retirement by a CEO who receives a new option award at age 65 and retires one year later. The dependent variable in the right two columns is a binary indicator that equals one for companies in which the value lost by executives who retire equals or exceeds the value lost by executives who die in office. Option values calculations use the Black-Scholes method, assuming stock price and exercise price of $\$ 25.00$, volatility of 0.30 , risk-free rate of 0.45 , dividend rate of 0.015 , and applying each company's policies for vesting, forfeiture, and truncation of option lives at retirement. The variable measuring years since the IPO date is capped at 80 years, the oldest age available on the CRSP database. The industry quit rate is computed from Bureau of Labor Statistics data. The California indicator equals one if the firm's corporate headquarters are located in that state. Standard errors appear in parentheses below each coefficient estimate.

\begin{tabular}{|c|c|c|c|c|}
\hline \multirow{3}{*}{$\begin{array}{l}\text { Dependent variable: } \\
\text { Estimation: } \\
\text { Firm size (log of total assets) }\end{array}$} & \multirow{2}{*}{\multicolumn{2}{|c|}{$\begin{array}{c}\text { Value lost at retirement } \\
\text { (percentage of award value) } \\
\text { OLS }\end{array}$}} & \multirow{2}{*}{\multicolumn{2}{|c|}{$\begin{array}{c}\text { Retiree value loss } \$ \\
\text { death value loss }(0,1) \\
\text { Logit }\end{array}$}} \\
\hline & & & & \\
\hline & $\begin{array}{l}-0.04^{\mathrm{a}} \\
(0.02)\end{array}$ & $\begin{array}{l}-0.03^{\mathrm{c}} \\
(0.02)\end{array}$ & $\begin{array}{l}-0.22^{\mathrm{b}} \\
(0.10)\end{array}$ & $\begin{array}{l}-0.21 \\
(0.14)\end{array}$ \\
\hline Firm age (log of years since IPO) & $\begin{array}{l}-0.08^{a} \\
(0.03)\end{array}$ & $\begin{array}{l}-0.06^{\mathrm{c}} \\
(0.03)\end{array}$ & $\begin{array}{l}-0.44^{\mathrm{b}} \\
(0.18)\end{array}$ & $\begin{array}{l}-0.38^{\mathrm{c}} \\
(0.22)\end{array}$ \\
\hline Sales growth (five year CAGR) & $\begin{array}{l}0.41^{\mathrm{b}} \\
(0.19)\end{array}$ & $\begin{array}{l}0.55^{\mathrm{b}} \\
(0.21)\end{array}$ & $\begin{array}{l}2.11^{\mathrm{c}} \\
(1.23)\end{array}$ & $\begin{array}{l}2.96^{\mathrm{c}} \\
(1.52)\end{array}$ \\
\hline R\&D / Sales & $\begin{array}{c}0.56^{\mathrm{c}} \\
(0.33)\end{array}$ & $\begin{array}{c}0.53 \\
(0.41)\end{array}$ & $\begin{array}{l}5.41^{\mathrm{b}} \\
(2.42)\end{array}$ & $\begin{array}{c}2.52 \\
(2.92)\end{array}$ \\
\hline Herfindahl Index & $\begin{array}{l}0.21^{\mathrm{c}} \\
(0.12)\end{array}$ & $\begin{array}{c}0.23 \\
(0.16)\end{array}$ & $\begin{array}{l}1.35^{\circ} \\
(0.76)\end{array}$ & $\begin{array}{l}2.86^{\mathrm{a}} \\
(1.00)\end{array}$ \\
\hline $\begin{array}{l}\text { Breadth of option plan } \\
\text { (pct. of awards beyond top five execs.) }\end{array}$ & $\begin{array}{l}-0.16 \\
(0.19)\end{array}$ & $\begin{array}{l}-0.36^{\mathrm{c}} \\
(0.21)\end{array}$ & $\begin{array}{l}-0.77 \\
(1.17)\end{array}$ & $\begin{array}{l}-1.76 \\
(1.41)\end{array}$ \\
\hline Industry quit rate & $\begin{array}{c}0.15 \\
(0.29)\end{array}$ & $\begin{array}{c}0.17 \\
(1.50)\end{array}$ & $\begin{array}{c}0.99 \\
(1.78)\end{array}$ & $\begin{array}{c}0.11 \\
(3.89)\end{array}$ \\
\hline $\begin{array}{l}\text { California location } \\
\text { (indicator) }\end{array}$ & $\begin{array}{r}0.22^{\mathrm{a}} \\
(0.06)\end{array}$ & $\begin{array}{l}0.15^{b} \\
(0.06)\end{array}$ & $\begin{array}{l}0.74^{\mathrm{b}} \\
(0.37)\end{array}$ & $\begin{array}{c}0.27 \\
(0.43)\end{array}$ \\
\hline $\begin{array}{l}\text { Software industry } \\
\text { (indicator) }\end{array}$ & & $\begin{array}{c}0.10 \\
(0.26)\end{array}$ & & $\begin{array}{r}3.59^{a} \\
(0.87)\end{array}$ \\
\hline Observations & 357 & 357 & 357 & 357 \\
\hline Industry indicators (Fama-French) & No & Yes & No & Yes \\
\hline Adjusted $\mathrm{R}^{2}$ & 0.165 & 0.216 & & \\
\hline F or Likelihood Ratio statistic & $9.79^{\mathrm{a}}$ & $2.96^{\mathrm{a}}$ & $51.66^{\mathrm{a}}$ & $89.83^{\mathrm{a}}$ \\
\hline
\end{tabular}

Significant at $1 \%(a), 5 \%(b)$, and $10 \%$ (c) levels. 


\section{Table 8 \\ Effect of firms' option sunset rules upon top executive turnover}

OLS regression analysis of top executive turnover as a function of companies' policies for treatment of stock options at retirement. Option forfeiture and truncation rules appear in company equity compensation plan documents filed with the SEC. The turnover rate for top executives is based upon changes in the listing of firms' five highest paid officers in company proxy statements, as reported by ExecuComp. The fitted value of the time to exercise options in retirement is obtained from the regression model presented in the fourth column of Table 6 . Standard errors appear below each estimate in parentheses. Both the turnover rate and stock return are compounded continuously. Although these variables are compiled over the period 1992 to 2004 for most companies, a shorter window is used for firms will less data available on ExecuComp.

Dependent variable:

Annual turnover rate among top 5 executive group, 1992-04

Cumulative stock return, 1992-2004

$-0.011^{a}$

$-0.011^{\mathrm{a}}$

Stock volatility

$0.087^{\mathrm{a}}$

$0.102^{\mathrm{a}}$

Time for option awards to vest

(weighted average, in months, $\mathrm{x} 10^{3}$ )

Forfeiture of unvested options at retirement

0.0003

0.001

(indicator)

Time to exercise options in retirement, actual

0.056

(maximum, in months, $\times 10^{3}$ )

(0.060)

Time to exercise options in retirement, predicted

$0.356^{\mathrm{b}}$

(fitted regression value, $\times 10^{3}$ )

Observations

Industry indicator variables

Yes

Yes

Adjusted $\mathrm{R}^{2}$

0.184

0.198

F-statistic

$2.71^{\mathrm{a}}$

$2.87^{\mathrm{a}}$

Significant at 1\% (a), 5\% (b), and 10\% (c) levels. 
Table 9

Impact of firms' sunset rules on reporting of early option exercises

Regression analysis of the impact of firms' sunset rules on reported patterns of option exercises. The dependent variable in the first two columns equals the fraction of the firm's total annual option exercises in fiscal years 2002 through 2004 that are reported at the person-level on the Thomson Financial insider trading database of Form 4 filings. Firm totals for annual option exercises are disclosed in footnotes to Form 10-K financial statements and were provided to us by Equilar, Inc. In the right two columns, the dependent variable equals the mean number of years prior to expiration at which executives exercise their options within each company, using all option exercises reported by Thomson Financial's Form 4 database. Standard errors appear in parentheses below each coefficient estimate.

\begin{tabular}{|c|c|c|c|c|}
\hline Dependent variable: & $\begin{array}{r}\text { Mean } \\
\text { exerci } \\
\text { (years be }\end{array}$ & $\begin{array}{l}\text { d early } \\
\text { ptions } \\
\text { piration) }\end{array}$ & $\begin{array}{r}\text { Fraction } \\
\text { option ex } \\
\text { on For }\end{array}$ & $\begin{array}{l}\text { m's total } \\
\text { s reported } \\
\text { atabase }\end{array}$ \\
\hline Intercept & $\begin{array}{l}2.137^{\mathrm{a}} \\
(0.469)\end{array}$ & & $\begin{array}{l}0.51^{\mathrm{a}} \\
(0.14)\end{array}$ & \\
\hline $\begin{array}{l}\text { Time to exercise options in retirement } \\
\text { exceeds one year (indicator) }\end{array}$ & $\begin{array}{l}-0.04 \\
(0.26)\end{array}$ & $\begin{array}{l}-0.09 \\
(0.26)\end{array}$ & $\begin{array}{l}-0.03^{\mathrm{b}} \\
(0.02)\end{array}$ & $\begin{array}{l}-0.04^{\mathrm{b}} \\
(0.02)\end{array}$ \\
\hline $\begin{array}{l}\text { Time for option awards to vest } \\
\text { (weighted average, in years) }\end{array}$ & $\begin{array}{l}-0.42^{\mathrm{a}} \\
(0.15)\end{array}$ & $\begin{array}{l}-0.37^{\mathrm{b}} \\
(0.15)\end{array}$ & $\begin{array}{c}0.01 \\
(0.01)\end{array}$ & $\begin{array}{c}0.01 \\
(0.01)\end{array}$ \\
\hline $\begin{array}{l}\text { Forfeiture of unvested options } \\
\text { at retirement (indicator) }\end{array}$ & $\begin{array}{l}-0.05 \\
(0.23)\end{array}$ & $\begin{array}{l}-0.27 \\
(0.23)\end{array}$ & $\begin{array}{l}-0.01 \\
(0.02)\end{array}$ & $\begin{array}{l}-0.01 \\
(0.02)\end{array}$ \\
\hline Stock volatility & $\begin{array}{l}3.65^{\mathrm{a}} \\
(0.96)\end{array}$ & $\begin{array}{l}2.88^{\mathrm{a}} \\
(1.12)\end{array}$ & $\begin{array}{c}0.01 \\
(0.06)\end{array}$ & $\begin{array}{l}-0.08 \\
(0.07)\end{array}$ \\
\hline Stock return, 2002-04 & $\begin{array}{l}4.13^{\mathrm{a}} \\
(0.68)\end{array}$ & $\begin{array}{l}4.63^{\mathrm{a}} \\
(0.71)\end{array}$ & $\begin{array}{c}0.17^{\mathrm{a}} \\
(0.041)\end{array}$ & $\begin{array}{l}0.18^{\mathrm{a}} \\
(0.05)\end{array}$ \\
\hline $\begin{array}{l}\text { Firm pays zero dividend in } 2004 \\
\text { (indicator) }\end{array}$ & $\begin{array}{l}-0.03 \\
(0.33)\end{array}$ & $\begin{array}{l}-0.07 \\
(0.33)\end{array}$ & $\begin{array}{l}0.03^{\mathrm{c}} \\
(0.02)\end{array}$ & $\begin{array}{l}0.04^{\mathrm{c}} \\
(0.02)\end{array}$ \\
\hline $\begin{array}{l}\text { Breadth of option plan (pct. of awards } \\
\text { beyond top five executives) }\end{array}$ & $\begin{array}{l}-1.34 \\
(0.97)\end{array}$ & $\begin{array}{l}-1.20 \\
(1.04)\end{array}$ & $\begin{array}{l}-0.45^{\mathrm{a}} \\
(0.06)\end{array}$ & $\begin{array}{l}-0.38^{\mathrm{a}} \\
(0.0 .07)\end{array}$ \\
\hline $\begin{array}{l}\text { Reload options awarded by firm } \\
\text { (indicator) }\end{array}$ & $\begin{array}{l}0.75^{\mathrm{b}} \\
(0.35)\end{array}$ & $\begin{array}{r}0.99^{\mathrm{a}} \\
(0.34)\end{array}$ & $\begin{array}{l}-0.004 \\
(0.02)\end{array}$ & $\begin{array}{l}-0.01 \\
(0.02)\end{array}$ \\
\hline Observations & 349 & 349 & 356 & 356 \\
\hline Industry indicator variables & Yes & No & No & Yes \\
\hline Fiscal year-end month indicators & Yes & Yes & Yes & Yes \\
\hline Adjusted $\mathrm{R}^{2}$ & 0.280 & 0.168 & 0.188 & 0.245 \\
\hline F-statistic & $3.18^{\mathrm{a}}$ & $4.50^{\mathrm{a}}$ & $5.11^{\mathrm{a}}$ & $2.86^{\mathrm{a}}$ \\
\hline
\end{tabular}

Significant at $1 \%(\mathrm{a}), 5 \%(\mathrm{~b})$, and $10 \%$ (c) levels. 


\section{Table 10 \\ Impact of sunset provisions upon option compensation of CEOs, by age}

Values of stock options and total compensation for CEOs in different age classes, with and without the impact of companies' sunset provisions for adjusting option terms when CEOs retire. The first two rows of the table show the number of CEOs in each age range who received stock options in 2004, and the number whose option values would be reduced at their expected retirement dates according to the rules of company option plans. Expected retirements are assumed to occur at age 65 for all CEOs in the first two columns, and one year past the current age of all CEOs in the right column. The middle rows of the table show mean values of option awards for the subsamples of CEOs in each age range, before and after the application of company policies for treatment of options at retirement. These policies, described more fully in Tables II and III, require the forfeiture of some unvested options and truncation of the remaining life of options that are not forfeited. All option values are calculated with the Black-Scholes formula using actual exercise prices and expirations, assumptions for volatility and dividend yield provided by ExecuComp, and a risk-free rate of $4.5 \%$. The bottom rows of the table show mean values of total compensation for CEOs in each age range, both with and without the option value reductions related to expected retirement dates. Total compensation is assumed to equal the sum of salary, bonus, restricted stock awards, stock option awards, long-term incentive plan payouts, and items disclosed as "other annual compensation" such as perquisites and retirement plan contributions. The table omits five CEOs who received options with certain performance conditions which made valuation difficult.

CEO age range

CEOs receiving options

Option values reduced at retirement

Percentage with values reduced

Option values without reductions, mean (000)

Option values with reductions, mean

Percentage change

CEOs in total sample

Total compensation, mean (000)

Total compensation after option value reductions, mean

Percentage change

$\begin{array}{ccc}61-62 & 63-64 & \begin{array}{c}65 \text { and } \\ \text { above }\end{array} \\ 35 & 14 & 17 \\ 17 & 11 & 14 \\ 49 \% & 79 \% & 82 \% \\ & & \\ \$ 8,688 & \$ 4,708 & \$ 8,705 \\ \$ 7,533 & \$ 2,626 & \$ 4,099 \\ -13 \% & -44 \% & -53 \% \\ & & \\ 40 & 18 & 31 \\ \$ 13,932 & \$ 10,267 & \$ 13,685 \\ \$ 12,777 & \$ 8,512 & \$ 10,279 \\ -8 \% & -17 \% & -25 \%\end{array}$



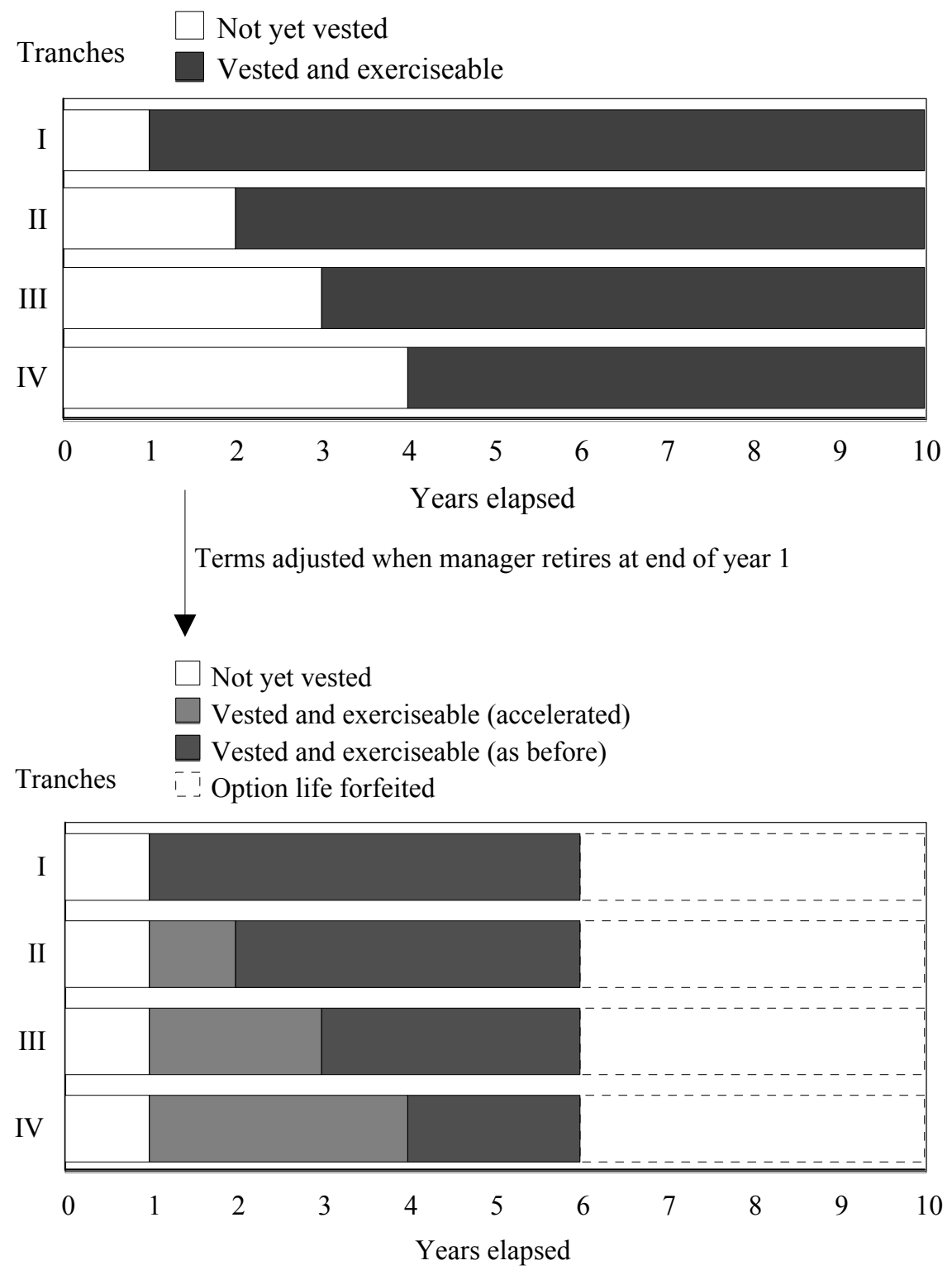

\section{Figure Ia}

\section{Adjustments to executive stock options when a manager retires: Time Warner}

The figure shows the intervals during which the separate tranches of an executive stock option award would be exerciseable for managers at Time Warner Inc. who retire one year after receiving an award. The top graph shows a typical award with a ten-year time to expiration and four tranches, which vest sequentially after each of the first four years. The bottom graph shows adjustments to the award if the option holder were to retire at the end of the first year. All of the tranches would vest immediately, but their expiration dates would be shortened from the tenth to the sixth year. The Black-Scholes value lost to the optionee as a result of these changes equals about $16 \%$ of the award date value, as shown in Table 1 . 

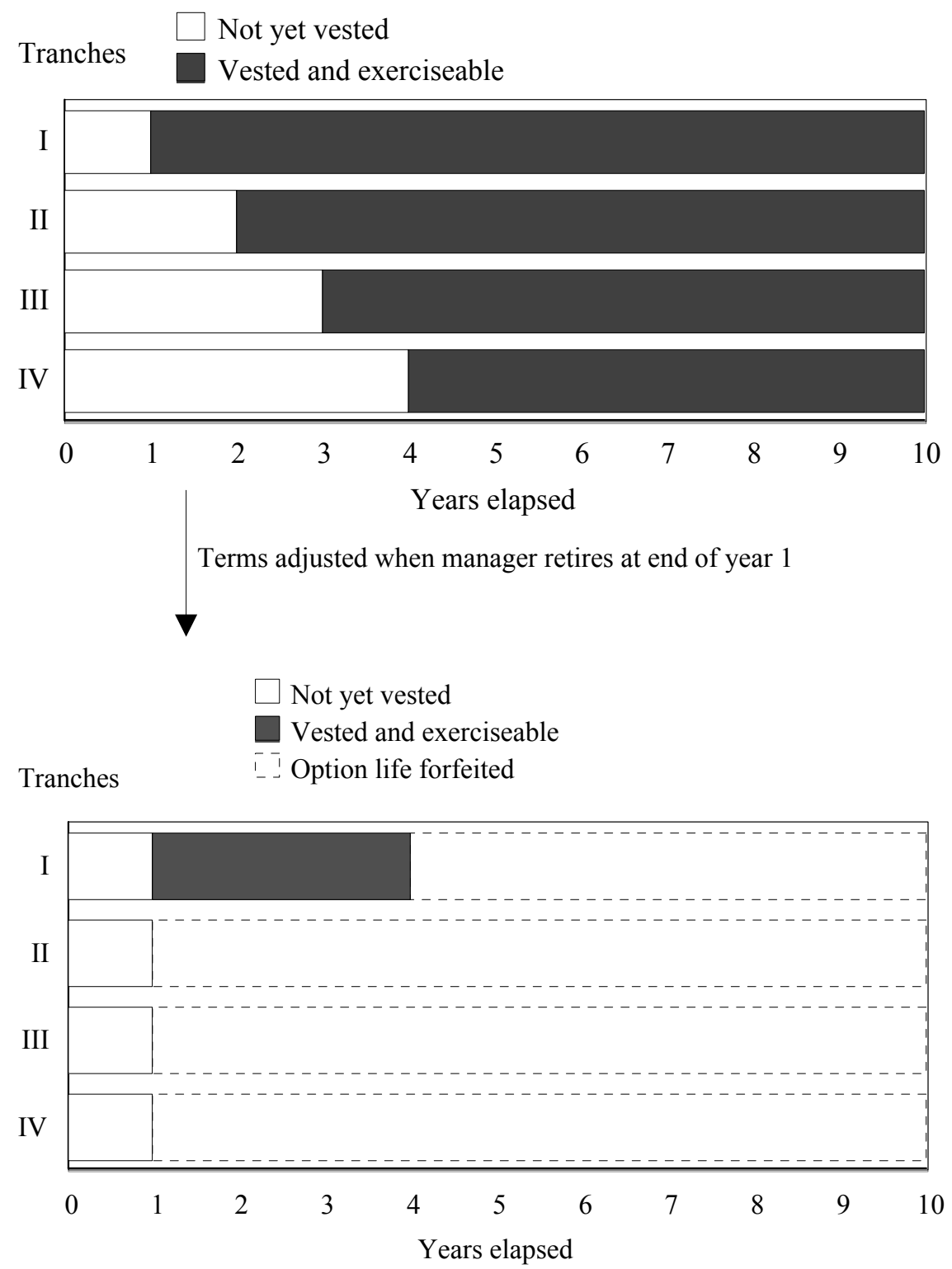

\section{Figure Ib}

Adjustments to executive stock options when a manager retires: Viacom

The figure shows the intervals during which the separate tranches of an executive stock option award would be exerciseable for managers at Viacom Inc. who retire one year after receiving an award. The top graph shows a typical award with a ten-year time to expiration and four tranches, which vest sequentially after each of the first four years. The bottom graph shows adjustments to the award if the option holder were to retire at the end of the first year. Three of the four tranches would be forfeited, and the expiration date for the other tranche would be shortened to the fourth year. The Black-Scholes value lost to the optionee as a result of these changes equals about $83 \%$ of the award date value, as shown in Table 1 . 


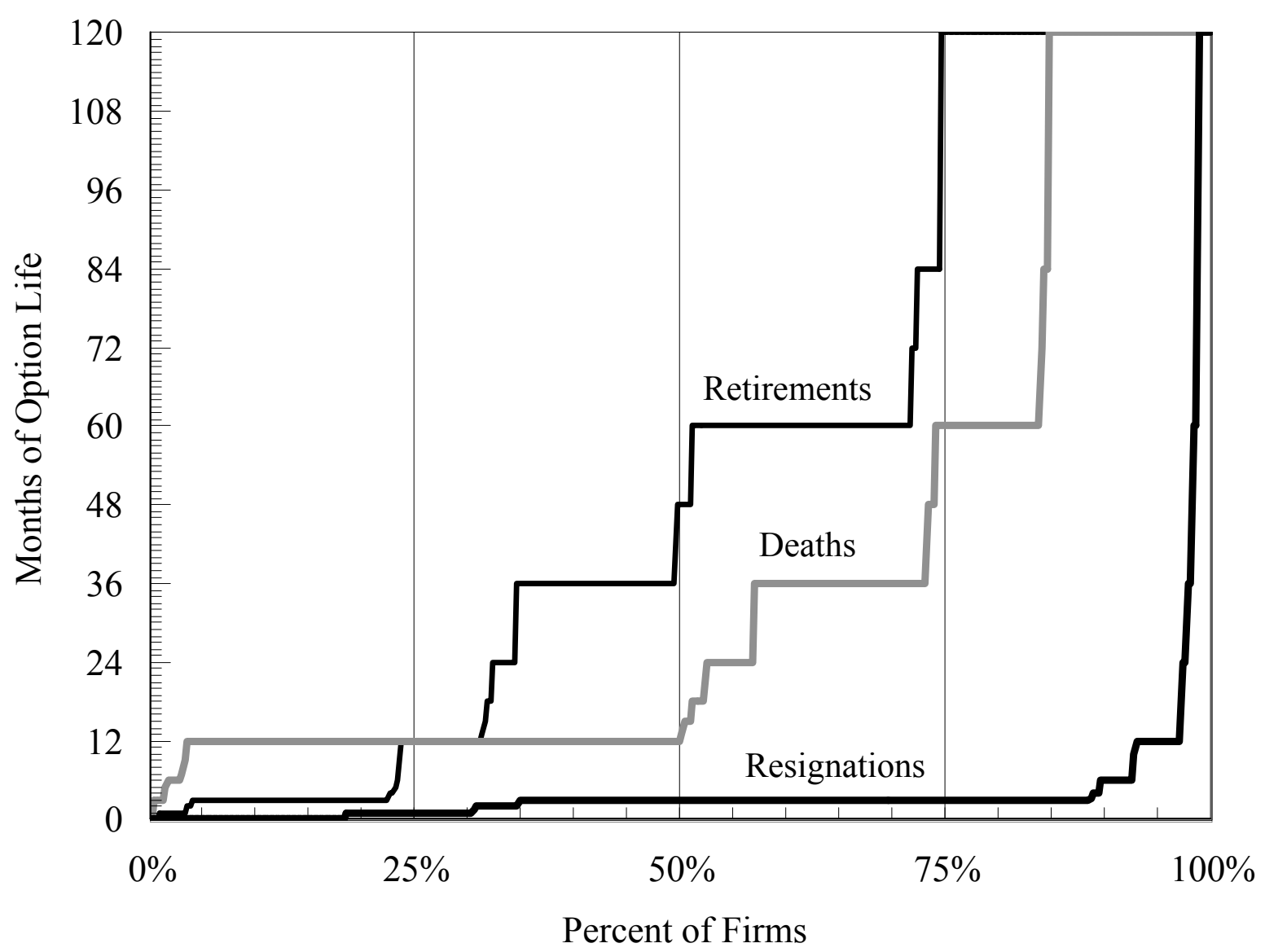

\section{Figure II}

Cumulative distributions of option life retained by managers who retire, resign, or die The figure shows the distribution of executive stock option maturities that managers in different companies would receive upon exiting their firms while holding unexercised options. The three lines tabulate firms' policies for managers' retirements, resignations, and deaths, with the differentiation between retirements and resignations generally depending on age and service criteria. In all cases, the value tabulated is the maximum maturity allowed to a manager; if the original option expiration date precedes the maximum time allowed, the manager simply retains the original expiration date. Data is obtained from executive compensation plan documents filed by 389 S\&P 500 firms with the SEC for the year 2005 . 


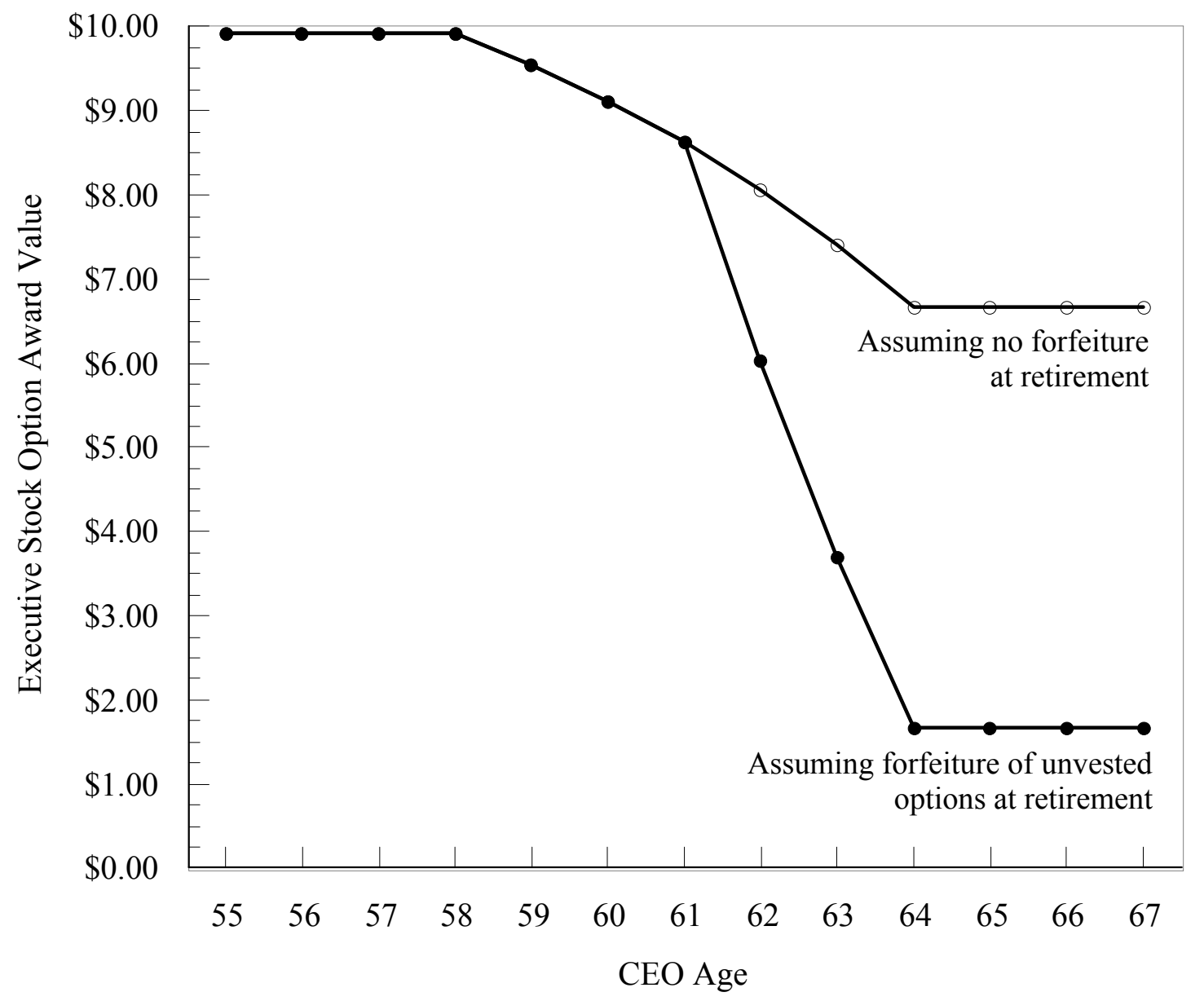

Figure III

Effect of company truncation and forfeiture policies on executive option values at award date

The figure shows the award date value of a representative CEO stock option based upon the age of the option holder at the time of the award. The option is assumed to be awarded with an exercise price of $\$ 25.00$, which is also the underlying stock price. The dividend yield is assumed to be 0.015 , volatility is 0.30 , and the risk-free rate is 0.045 . As shown in the graph, this option has a Black-Scholes award value of close to $\$ 10.00$ for executives at age 58 or younger. All executives are assumed to retire at age 65 , and at retirement, the remaining option life is shortened to three years (or is left unchanged if the remaining life is below three years). The top line in the graph shows the value consequences of this truncation of option life. In addition, the option award is assumed to vest in four annual installments. If the unvested options are forfeited when the executive retires, the value consequences of this forfeiture are shown in the lower line, which also reflects the value lost due to the shortening of vested option lives to a maximum of three years. The option parameters and retirement policies illustrated in the figure are chosen to reflect the typical practices of of companies in the overall sample. 